University of Wollongong

Research Online

$1-1-2018$

Effect of non-IFRS earnings reporting guidelines on underlying earnings reporting quality: The case of Australian listed firms

\author{
Yiru Yang \\ University of Wollongong, yy449@uowmail.edu.au \\ Indra Abeysekera \\ Charles Darwin University, indraa@uow.edu.au
}

Follow this and additional works at: https://ro.uow.edu.au/buspapers

Part of the Business Commons 


\title{
Effect of non-IFRS earnings reporting guidelines on underlying earnings reporting quality: The case of Australian listed firms
}

\author{
Abstract \\ This study investigates Australian Securities Exchange (ASX) 200 firms in the post-Australian Securities \\ and Investments Commission (ASIC) period (2011-2014) to examine how listed firms follow the non- \\ International Financial Reporting Standards (IFRS) earnings reporting guidelines issued by ASIC to \\ communicate underlying earnings reporting quality. We find that firms that do not comply with the ASIC \\ guidelines have lower underlying earnings reporting quality than do firms that comply with these \\ guidelines. Firms that do not follow the ASIC guidelines are found to exclude income-increasing \\ underlying earnings adjustments to make underlying earnings appear more profitable than IFRS earnings \\ when they miss earnings targets or make current losses, and that they report underlying earnings \\ opportunistically by excluding recurring expenses that persist into future operating earnings. Unlike ASIC \\ non-compliance firms, ASIC compliance firms attempt to act as responsible reporters by reporting \\ underlying earnings in a responsible manner to demonstrate a judicious use of discretion in informing \\ shareholders. Further, we find that underlying earnings reported by non-compliance firms are less value- \\ relevant than underlying earnings reported by compliance firms.

\section{Disciplines \\ Business}

\section{Publication Details} \\ Yang, Y. \& Abeysekera, I. (2018). Effect of non-IFRS earnings reporting guidelines on underlying earnings \\ reporting quality: The case of Australian listed firms. Journal of International Financial Management and \\ Accounting, 29 (3), 312-338.
}




\title{
Effect of non-IFRS Earnings Reporting Guidelines on Non-IFRS Earnings
}

Reporting Quality: The Case of Australian Listed Firms

\author{
Yiru Yang, ${ }^{\mathrm{a}}$ Indra Abeysekera ${ }^{\mathrm{b}}$ \\ ${ }^{a}$ School of Accounting, Economics and Finance, University of Wollongong, \\ Wollongong, NSW, Australia \\ ${ }^{\mathrm{b}}$ Charles Darwin University, Australia
}




\begin{abstract}
This study uses data on Australian Securities Exchange (ASX) 200 firms for 2011-2014 to examine the impacts of Australian Securities and Investments Commission (ASIC) non-International Financial Reporting Standards (non-IFRS) earnings reporting guidelines on non-IFRS earnings reporting quality. We find that firms that do not comply with the ASIC guidelines have lower non-IFRS earnings reporting quality than do firms that comply with these guidelines. The former firms opportunistically exclude recurring expenses from IFRS earnings to ensure non-IFRS earnings appear more profitable than IFRS earnings when they miss earnings targets or incur current losses. The latter firms act as responsible reporters by judiciously using their discretion to efficiently report non-IFRS earnings. The findings indicate that although ASIC has issued guidelines to limit firms' opportunistic non-IFRS earnings reporting, but opportunistic non-IFRS earnings reporting is still present in non-compliance firms. We suggest mandatorily enforcing the guidelines on non-IFRS earnings reporting firms to mitigate such opportunistic reporting. Where possible, ASIC should increase its enforcement action against firms that do not comply with these guidelines.
\end{abstract}

Keywords: Australian Securities and Investments Commission, earnings target, earnings losses, earnings adjustments, non-IFRS earnings, reporting quality, value relevance

JEL Classification: M41 Accounting 


\section{Introduction}

In recent decades, reporting non-International Financial Reporting Standards (non-IFRS) earnings has become a common practice in countries worldwide. This began in the 1990s in the United States (US) and spread worldwide (Bhattacharya et al., 2003; Bradshaw and Sloan, 2002; Doyle et al., 2003). Non-IFRS earnings, commonly known as non-Generally Accepted Accounting Principles (non-GAAP) earnings, reported by managers in the US, provide alternate and unaudited earnings measures of firm performance. Non-GAAP earnings are also referred to as "recurring earnings," "core earnings," "pro forma earnings," "underlying earnings", and "adjusted earnings." Non-GAAP earnings represent recurring cash-related earnings and exclude nonrecurring and non-cash items. Firms argue that non-recurring and non-cash items do not reflect monetarily measured underlying firm performance (Bradshaw and Sloan, 2002; Brown and Sivakumar, 2003; Bhattacharya et al., 2004). Managers consider that nonGAAP earnings can help investors make better decisions because such earnings provide information on firms' recurring economic performance (Albring et al., 2010; Collins et al., 2009). Non-GAAP earnings reported by firms have received considerable research attention, with some researchers finding that non-GAAP earnings help investors improve decision-making because of the availability of more accurate information on firm performance (e.g., Bhattacharya et al., 2003; Bradshaw and Sloan, 2002; Collins et al., 2009; Brown and Sivakumar, 2003), while others find that nonGAAP earnings do not improve investors' decision-making because managers' report non-GAAP earnings to obtain personal economic benefits (e.g., meeting set earnings targets) or to unduly influence investors' perceptions about firm performance (e.g., Doyle et al., 2003; Johnson and Schwartz, 2005; Black and Christensen, 2009). 
This paper considers that "non-IFRS earnings" which are similar to the nonGAAP earnings reported in the US. Non-IFRS earnings and non-GAAP earnings are calculated by preparers using their judgment to reflect "core" or "recurring" business activities of the reporting firm. Both types of earnings are voluntarily reported, and calculated by adjusting statutory earnings.

However, from a reporting and regulatory perspective, non-IFRS earnings and non-GAAP earnings differ in two ways. First, the adjustment items excluded from nonGAAP earnings reported by US firms differ from the adjustment items excluded from non-IFRS earnings reported by Australian firms. US firms use several common adjustment items: stock-based compensation costs, tax and interest effects, merger and acquisition costs, expensed research and development costs, depreciation and amortization costs, and gains and losses on asset dispositions (Bhattacharya et al., 2003; Bhattacharya et al., 2004; Black and Christensen, 2009). The common adjustment items made to non-IFRS earnings by Australian firms are impairment and/or revaluation of assets, losses and/or gains on disposal of assets and business, and restructuring costs (Deloitte, 2010; KPMG, 2009).

Second, unlike in the US, ${ }^{1}$ there is no compulsory regulation governing managers' reporting on non-IFRS earnings in Australian firms. The Australian Securities and Investments Commission (ASIC) issued Consultation Paper 150 in March 2011, proposing guidelines to minimize any adverse effect that may result from firms reporting non-IFRS earnings. The guidelines state the following: (i) managers

\footnotetext{
${ }^{1}$ The SEC introduced Regulation G (Reg G), item 10(e) of Regulation S-K, and item 12 to govern non-GAAP earnings reported outside financial statements in 2003. Reg $G$ includes all the public reporting of non-GAAP financial evaluation containing conference calls, press releases, presentations to investors, and other forms of media. In order to establish transparency in calculating non-GAAP earnings, the regulation demands that the reporters reconcile non-GAAP earnings with GAAP earnings. While the SEC attempts to ensure non-GAAP earnings reporting is useful and has not been completed in a misguided manner, it does not prohibit non-GAAP reporting (SEC, 2003).
} 
should explain the calculation of non-IFRS earnings and why it is important to report them; (ii) firms should not provide greater prominence to non-IFRS earnings than to IFRS information; (iii) managers should provide a reconciliation between non-IFRS earnings and IFRS earnings; and (iv) firms should consistently report non-IFRS earnings (ASIC, 2011a). In December 2011, ASIC published its Regulatory Guide 230: Disclosing Non-IFRS Financial Information as a guide to clarify reporting of non-IFRS earnings, with the aim of preventing the users being misguided by non-IFRS earnings reporting. ASIC's Regulatory Guide 230 states that firms can report non-IFRS earnings in communications such as directors' reports, press releases, notes to financial statements, and analyst briefings, but that reporting should not mislead financialstatement users by giving greater prominence to non-IFRS earnings than IFRS earnings information. Firms can report non-IFRS earnings when that reporting assists in providing a true and fair view of financial statements. Firms must also reconcile nonIFRS earnings and IFRS earnings by showing and explaining adjustments (ASIC, 2011b). These guidelines are similar to Reg G in the US; however, it is mandatory for firms that report non-GAAP earnings to follow Reg G but it is voluntary for firms that report non-IFRS earnings to follows ASIC's guidelines. The differences in adjustment items and regulatory requirements between Australian and US firms mean that Australia allows a setting for the investigation of the role of reporting non-IFRS earnings in the context of a voluntary-reporting environment shaped by ASIC guidelines.

This study examines how Australian listed firms follow the non-IFRS earnings reporting guidelines issued by ASIC in 2011 to report non-IFRS earnings. We examine the non-IFRS earnings reporting quality of firms that comply or do not comply with the ASIC guidelines in the post-ASIC period. We also examine the value relevance of the 
non-IFRS earnings reporting for ASIC non-compliance firms and ASIC compliance firms in the post-ASIC period. This study selected ASX 200 firms as they represent the principal investment benchmark in Australia and examined from years 2011 to 2014.

The results show that firms that do not comply with the ASIC guidelines opportunistically exclude recurring expenses when those firms miss earnings targets or make current losses. In contrast, firms that comply with the ASIC guidelines tend to report non-IFRS earnings efficiently. Specifically, non-IFRS earnings adjustments made by compliance firms do not persist into future operating earnings, indicating that ASIC compliance firms tend to act as responsible reporters. The results suggest that firms that do not voluntarily follow ASIC's non-IFRS reporting guidelines have lower non-IFRS earnings reporting quality than firms that follow the guidelines. In addition, we find that the market perceives the non-IFRS earnings reported by non-compliance firms to be more value relevant than such earnings reported by compliance firms when the former firms use income-increasing exclusions to report higher non-IFRS earnings than IFRS earnings to meet IFRS earnings targets and avoid IFRS losses. This finding suggests that for non-compliance firms, the value relevance of non-IFRS earnings derives from managers' opportunistic behavior of excluding income-increasing non-IFRS earnings adjustments, and investors are misled.

This paper makes two significant contributions. First, prior research in the US provides mixed results about managers' motivations to report non-GAAP earnings in the context of mandatory reporting guidelines. Such motivations are not examined in the context of voluntary reporting guidelines. To the best of our knowledge, this study is an early contributor to the literature on voluntary reporting in its investigation of the non- 
IFRS earnings reporting quality of firms that voluntarily comply or do not comply with ASIC guidelines. Second, this study contributes empirical evidence to the literature on non-IFRS earnings reporting by examining the types of expense adjustments made to IFRS earnings to determine non-IFRS earnings by firms that comply with or firms that do not comply with the voluntary ASIC guidelines.

The remaining sections of the paper are organized as follows. Section 2 examines the relevant literature and presents the hypotheses developed in this study. Section 3 discusses the research design. Section 4 presents the data analyses and regression results. Section 5 presents the additional tests. Section 6 presents the study conclusions.

\section{Literature Review and Hypothesis Development}

\subsection{Motivations for Non-GAAP Earnings Reporting}

Studies have examined whether managerial discretion in reporting non-GAAP earnings helps investors to ascertain more accurately the underlying economic reality of the firm (efficient reporting motivation) or perpetuates managers' interests (opportunistic reporting motivation). This paper provides evidence from the empirical studies conducted that reveal the presence of both types of reporting motivation.

\subsubsection{Evidence of efficient reporting motivation}

A range of arguments highlight the potential benefits of non-GAAP earnings reporting made by managers. Bradshaw and Sloan (2002) compared the value relevance of non-GAAP earnings with the value relevance of GAAP earnings. These authors first demonstrated that a substantial portion of exclusions from non-GAAP earnings are nonrecurring expenses. The research found that the earnings response coefficients and regression $\mathrm{R}^{2}$ were much higher for non-GAAP earnings than for GAAP earnings, 
suggesting that investors perceive non-GAAP earnings as more relevant. Brown and Sivakumar (2003) extended Bradshaw and Sloan's (2002) study by investigating three qualitative attributes of non-GAAP earnings for value relevance: the capacity to forecast future earnings with stock prices (predictive ability); correlating earnings with stock prices (valuation); and associating earnings with abnormal stock returns (information content). The authors found that non-GAAP earnings is a better measure of predictive ability, valuation, and information content than GAAP earnings. Bhattacharya et al. (2003) investigated whether non-GAAP earnings reported by managers are more persistent and informative than GAAP operating earnings, finding that non-GAAP earnings are much more informative and persistent than GAAP operating earnings, implying that market participants consider that non-GAAP earnings represent "core earnings" better than GAAP earnings. Collins et al. (2009) used abnormal-returns volatility, abnormal returns, and abnormal trading volume around quarterly-earnings announcement dates to examine the value relevance of non-GAAP earnings. The authors found that market participants increasingly rely on non-GAAP earnings for their stock-pricing decisions. Albring et al. (2010) examined whether reported non-GAAP earnings are more relevant than GAAP earnings, using the stock-prices model and stock-returns model. The results demonstrated that non-GAAP earnings are strongly associated with stock prices and stock returns, suggesting that non-GAAP earnings are more relevant to investors than are GAAP earnings. Choi et al. (2007) investigated the specific sources of disagreement between analysts and management in relation to the components of non-GAAP earnings in the United Kingdom (UK) context. They found that most management-specific adjustments made in non-GAAP earnings are nonrecurring items, and are more useful for increasing the persistence aspect of non-GAAP 
earnings than are specific adjustments made by analysts. These results suggest that management-specific adjustments to GAAP earnings reveal managers' superior knowledge of the persistence aspect of earnings components.

\subsubsection{Evidence of opportunistic reporting motivation}

In contrast, studies have also found evidence that managers opportunistically report non-GAAP earnings when GAAP earnings cannot meet earnings thresholds. Managers' report non-GAAP earnings to meet or beat GAAP earnings targets by excluding recurring-earnings components from GAAP earnings. Doyle et al. (2003) investigated persistent exclusions made by managers when calculating non-GAAP earnings and discovered that the expenses excluded from GAAP earnings in calculating non-GAAP earnings are value relevant to future earnings, suggesting that non-GAAP earnings are manipulated by managers. Johnson and Schwartz (2005) employed a between-samples design to compare the characteristics of firms that report non-GAAP earnings and those that do not, and found no difference in the persistence in GAAP earnings per share (EPS) of firms that report non-GAAP earnings and those that do not report such earnings. The narrow-window stock-returns tests revealed no evidence of a stock-returns premium for firms reporting non-GAAP earnings at the quarterly-earnings announcement date. Although investors were not misled by non-GAAP earnings reporting, the authors question managers' assertions that reporting non-GAAP earnings is intended to help investors assess firm performance. Landsman et al. (2007) examined the components of earnings that are excluded from GAAP earnings to reach non-GAAP earnings to determine the value relevance of non-GAAP earnings. The authors employed three quality attributes in their study: abnormal earnings forecasting, predictability of exclusions, and valuation of exclusions. The findings demonstrated that 
the market misprices manager-led positive and negative exclusions, special items, and other types of exclusions made in non-GAAP earnings reporting, suggesting that managers mislead the market through a non-GAAP reporting strategy. Black and Christensen (2009) studied the adjustments that managers make in reporting non-GAAP earnings, and discovered that managers exclude recurring items from GAAP earnings to define non-GAAP earnings to meet strategic earnings targets. Elshafie et al. (2010) investigated the relationship between investor-perception management achieved through reporting non-GAAP earnings opportunistically and real-activities earnings management or accruals earnings management. Their research found that managers tend to report non-GAAP earnings opportunistically if they do not meet their earnings targets or if they have limited ability in managing earnings through two other earningsmanagement techniques (i.e., real-activities earnings management and accruals earnings management). Barth et al. (2012) examined the differences in recognizing stock-based compensation expenses when managers calculate non-GAAP earnings and analysts also calculate and report street earnings to understand whether managers' incentives to report non-GAAP earnings differ from analysts' street earnings. They found that managers exclude stock-based compensation expenses from their non-GAAP earnings calculations to increase the non-GAAP earnings they report. These managers were found to report smoothed earnings across reporting periods, and meet earnings benchmarks when GAAP earnings did not. This opportunistic motivation was also found to exist in analysts' street-earnings reporting. Analysts are motivated to manage investor perceptions of the performance of the firms they follow, suggesting that analysts curry favor with managers. 
Opportunistic non-GAAP earnings reporting behavior also exists outside the US such as in European countries. For example, Hitz (2010) investigated the determinants of firms' decisions to report non-GAAP earnings in a largely unregulated setting in the German capital market and discovered that firms emphasize non-GAAP earnings more than GAAP earnings. Hitz (2010) found that firms that do not meet earnings benchmarks under GAAP earnings are much more likely to report non-GAAP earnings than firms that meet or beat these benchmarks under GAAP earnings. In addition, Isidro and Marques (2014) used hand-collected data for a sample of large European firms to study the effect of economic factors and countries' institutional structure on managers' non-GAAP earnings reporting. They found that countries with efficient legislative systems that provide strong protection for investors with a developed capital market, and with sound communicational channels tend to utilize non-GAAP reporting to meet or beat earnings targets.

\subsection{Regulatory Response to Non-GAAP Earnings}

Various empirical studies have examined the influences of regulation on nonGAAP earnings reporting, with some findings demonstrating that Reg G in the US has resulted in a decline in the non-GAAP earnings reported. For example, Marques (2006) documented that the average percentage of firms that report non-GAAP earnings decreased after the introduction of Reg G. According to Heflin and Hsu (2008), not only did the frequency of non-GAAP earnings reporting decrease, but also the number of exclusions showing discrepancies between GAAP and non-GAAP earnings decreased. However, this declining trend reversed to an upward trend in 2012 in the US (Black et al., 2012). After the introduction of Reg G, studies found that the quality of non-GAAP earnings reported increased. The quality of such reporting has several dimensions. 
Firms reported less opportunistic non-GAAP measures (Bowen et al, 2005). Potentially misleading reporting practices also decreased (Entwistle et al., 2006). Confidence in the market increased (Marques, 2006). The probability that firms disclose non-GAAP earnings to meet or beat forecasts declined (Heflin and Hsu, 2008). Firms restrained from mispricing (Zhang and Zheng, 2011).

\subsection{Hypothesis Development}

The literature has documented that when firms miss earnings targets, they tend to report non-GAAP earnings (which is equivalent to non-IFRS earnings in Australia) aggressively (i.e., the non-GAAP earnings is reported higher than GAAP earnings) to meet earnings targets or to avoid earnings losses (e.g., Elshafie et al., 2010; Hitz, 2010). First, this study attempts to examine whether non-compliance firms tend to report nonIFRS earnings aggressively by excluding income-increasing non-IFRS earnings adjustments from IFRS earnings, when they miss earnings targets or make IFRS losses compared with compliance firms. Given that this paper is the first to examine the nonIFRS earnings reporting quality of firms that voluntary comply or do not comply with the ASIC guidelines, and that non-GAAP reporting shows mixed evidence in a regulatory compliance environment, this paper states hypothesis 1 in null form as follows:

H1: There is no difference in the income-increasing non-IFRS earnings adjustments made by ASIC compliance firms and ASIC non-compliance firms, when firms miss earnings targets or make losses.

Secondly, this study attempts to investigate whether aggressive non-IFRS earnings is reported by managers opportunistically. Opportunistic non-IFRS earnings reporting is perceived as a less costly earnings-management technique because it is less 
likely to be detected by investors than other earnings-management techniques. From a valuation perspective, if the probability of detecting an earnings-management technique is low, it is less costly than other earnings-management techniques (Badertscher et al., 2012). Opportunistic non-IFRS earnings reporting is much easier to process than trying to identify whether a firm has engaged in real or accruals-based earnings management (Black et al., 2017). Another advantage of opportunistic non-IFRS earnings reporting is that it enables management to manage earnings in large amounts without accounting for the adjustments in the accounting-information system because this adjustment information is used for reporting purposes only, which enables management to achieve specific reporting benchmarks (Black et al., 2017; Badertscher, 2011).

The literature describes opportunistic non-IFRS earnings reporting as a situation where if non-IFRS earnings adjustments contain recurring expenses that persist into future operating earnings, these recurring expenses, which are persistent from one reporting period to another, will be realized in future operating earnings (e.g., Doyle et al., 2003; Frankel et al., 2011). This paper examines the persistence of incomeincreasing non-IFRS earnings adjustments for reporting firms that comply or do not comply with the ASIC guidelines. Given that no study has examined how firms follow the ASIC guidelines to report income-increasing non-IFRS earnings adjustments, the second hypothesis in this paper is stated in two parts to establish the total situation and reporting situations by individual adjustments, as follows:

H2a: There is no difference in the persistence of total income-increasing nonIFRS earnings adjustments between ASIC compliance firms and ASIC noncompliance firms.

H2b: There is no difference in the persistence of individual income-increasing 
non-IFRS earnings adjustments between ASIC compliance firms and ASIC noncompliance firms.

To date, empirical evidence does not provide clear evidence on the value relevance of non-GAAP earnings. A stream of evidence demonstrates that non-GAAP earnings are value relevant to the market (e.g., Bradshaw and Sloan, 2002; Brown and Sivakumar, 2003; Bhattacharya et al., 2003). However, there is also evidence to demonstrate that the value relevance of non-GAAP earnings results from managers opportunistically excluding recurring adjustments from GAAP earnings (e.g., Doyle et al., 2003; Frankel et al., 2011). These findings on non-GAAP earnings relate to a reporting period under a mandatory reporting regime; however, the present study tests market responses in a context of voluntary statutory intervention. Given that the value relevance of non-IFRS earnings is an open and testable question, the influence of ASIC's guidelines on value-relevant non-IFRS earnings is yet unspecified. This paper states the value-relevance hypothesis in null form as follows:

H3: There is no difference in the value relevance of non-IFRS earnings between ASIC compliance firms and ASIC non-compliance firms.

\section{Research Design}

\subsection{Data and Sample Selection}

This study focuses on the post-ASIC period and uses ASX 200 firms from years 2011 to 2014 as the sample frame. ASX 200 firms were selected as the sample frame because the ASX 200 is recognized as the primary investment benchmark in Australia, and ASX 200 firms cover approximately $78 \%$ of Australian equity market capitalization. The financial data were collected from the DatAnalysis database. We hand collected the non-IFRS earnings data from the annual reports of ASX 200 firms. 
Following Dahmash et al. (2009), we excluded firms involved in banking, insurance, diversified financials, and real estate because they are subject to different reporting requirements.

To collect the non-IFRS earnings data, we searched for information on nonIFRS earnings reported in the annual reports that are available in the Annual Reports Online database and DatAnalysis database by typing the keywords "underlying", "adjusted", "normalized", “non-IFRS", “earnings before”, "profit before”, and "pro forma”. Following Black and Christensen (2009), we excluded earnings before interests and taxes (EBIT) and earnings before interests, taxes, depreciation, and amortization (EBITDA) because these earnings are commonly reported as standard steps in the income statement. If a firm complies with all of ASIC's guidelines-(i) firms explain the calculation of non-IFRS earnings and why it is important to report them; (ii) firms do not provide greater prominence to non-IFRS earnings than to IFRS earnings, (iii) firms provide a reconciliation between non-IFRS earnings and IFRS earnings, (iv) firms consistently report non-IFRS earnings (ASIC, 2011a, 2011b) —over the four reporting periods from 2011 to 2014, then the study consider the firm a compliance firm.

Table 1 presents the sample-selection process in detail. The study found 131 of 152 firms had reported non-IFRS earnings at least once during the study period (20112014). In total, 407 firm-year observations of 608 firm-year observations in the sample disclosed non-IFRS earnings. Forty-six firms, which account for 184 firm-year observations, disclosed non-IFRS earnings that comply with ASIC guidelines over four observation years. Eighty-five firms (i.e., 131 minus 46), and 223 firm-year 
observations (i.e., 407 minus 184) reported non-IFRS earnings that do not comply with ASIC guidelines.

$<$ Insert Table 1 about here $>$

\subsection{Earnings Target, Earnings Losses, and Non-IFRS earnings Adjustments (H1)}

Following Lougee and Marquardt (2004) and Elshafie et al. (2010), this paper used previous-year earnings before tax at the end of the financial year as a proxy for earnings target. Firms that generated earnings before tax at the end of the current financial year that were less than the earnings before tax of the previous financial year were considered to represent managers that have missed their earnings targets $\left(\mathrm{Miss}_{\mathrm{j}, \mathrm{t}}\right)$, such firms were coded 1 , and zero otherwise. This paper defines $\operatorname{Loss}_{\mathrm{j}, \mathrm{t}}$ as a dummy variable that equals 1 if firm $\mathrm{j}$ made IFRS losses in year $\mathrm{t}$, and zero otherwise.

The empirical models for testing $\mathrm{H} 1$ are designed as follows:

$A D J_{j, t}=a_{0}+a_{1} \operatorname{Miss}_{j, t}+a_{2} \operatorname{Loss}_{j, t}+a_{3} N C P L_{j, t}+a_{4} \operatorname{Miss}_{j, t} * N C P L_{j, t}+a_{5} \operatorname{Loss}_{j, t} * N C P L_{j, t}$

$+a_{6}$ Controls $_{j, t}+e_{j, t}$

Where $\mathrm{j}$ is firm-year observations, and $\mathrm{t}$ is years from 2011 to $2014 . \mathrm{ADJ}_{\mathrm{j}, \mathrm{t}}$ is the total actual income-increasing non-IFRS earnings adjustments divided by the number of shares outstanding for firm $\mathrm{j}$, in year $\mathrm{t}$. It is calculated as the actual non-IFRS earnings figures minus the IFRS earnings figures divided by the number of shares outstanding for firm $\mathrm{j}$, in year $\mathrm{t}$. We keep positive $A D J_{\mathrm{j}, \mathrm{t}}$ and set negative $\mathrm{ADJ}_{\mathrm{j}, \mathrm{t}}$ as 0 because we focus only on income-increasing adjustments. Miss $_{\mathrm{j}, \mathrm{t}}$ is a dummy variable that equals 1 if firm j's earnings before tax in year $\mathrm{t}$ are less than earnings before tax in year $\mathrm{t}-1$, and zero otherwise. $\operatorname{Loss}_{\mathrm{j}, \mathrm{t}}$ is a dummy variable that equals 1 if firm $\mathrm{j}$ made IFRS losses in 
year $\mathrm{t}$, and zero otherwise. $\mathrm{NCPL}_{\mathrm{j}, \mathrm{t}}$ is a dummy variable that equals 1 if firm $\mathrm{j}$ does not comply with ASIC guidelines to report non-IFRS earnings in year $t$, or 0 otherwise. $\operatorname{Miss}_{\mathrm{j}, \mathrm{t}}{ }^{*} \mathrm{NCPL}_{\mathrm{j}, \mathrm{t}}$ is the interaction term between $\operatorname{Miss}_{\mathrm{j}, \mathrm{t}}$ and NCPL $\mathrm{j}_{\mathrm{j}, \mathrm{t}} \cdot \operatorname{Loss}_{\mathrm{j}, \mathrm{t}}$ *NCPL $\mathrm{L}_{\mathrm{j}, \mathrm{t}}$ is the interaction term between Loss $_{\mathrm{j}, \mathrm{t}}$ and $\mathrm{NCPL}_{\mathrm{j}, \mathrm{t}}$. Control variables are discussed in Section 3.4 .

\subsection{Persistence of Income-increasing Non-IFRS earnings Adjustments (H2)}

Doyle et al. (2003) found that adjustments to GAAP-based earnings made by managers are not entirely transitory because current recurring items are realized in future cash flows. Frankel et al. (2011) also confirmed this. However, both studies examined the persistence of total non-GAAP exclusions measured as non-GAAP EPS minus GAAP EPS. Kolev et al. (2008) found non-GAAP adjustments to be of higher quality following intervention by the Securities and Exchange Commission (SEC) in non-GAAP earnings. Further, these authors found that firms that stopped reporting nonGAAP earnings after intervention by the SEC had lower quality adjustments in the preintervention period. In those studies, the total non-GAAP exclusions include incomedecreasing and income-increasing exclusions. In contrast, this paper considers that when firms miss the IFRS earnings targets or make IFRS earnings losses, they tend to use income-increasing non-IFRS earnings adjustments to make their report more favorable than if they reported only IFRS earnings. This paper not only examines the persistence of total income-increasing non-IFRS earnings adjustments but also extends previous literature by examining the persistence of individual income-increasing nonIFRS earnings adjustments. If income-increasing non-IFRS earnings adjustments are presented faithfully by managers, and that is where income-increasing adjustments are deemed as value irrelevant, then those adjustments should not relate to future operating 
earnings. However, if income-increasing non-IFRS earnings adjustments include information that is useful for future earnings, then there is a relationship between future operating earnings and income-increasing non-IFRS earnings adjustments because these adjustments are realized in future years. The empirical models for testing $\mathrm{H} 2 \mathrm{a}$ and $\mathrm{H} 2 \mathrm{~b}$ are presented below.

Test for $\mathrm{H} 2 \mathrm{a}$

$$
\begin{aligned}
& O E_{j, t+1}=a_{0}+a_{1} U E P S_{j, t}+a_{2} A D J_{j, t}+a_{3} N C P L_{j, t}+a_{4} A D J_{j, t} * N C P L_{j, t}+a_{5} \text { Controls }_{j, t} \\
& +v_{j, t} \\
& O E_{j, t+1}=a_{0}+a_{1} U E P S_{j, t}+a_{2} A D J_{j, t}+a_{3} N C P L_{j, t}+a_{4} A D J_{j, t} * N C P L_{j, t}+a_{5} M_{i s s_{j, t}}+ \\
& a_{6} A_{D} J_{j, t} * \text { Miss }_{j, t} * N C P L_{j, t}+a_{7} \text { Controls }_{j, t}+v_{j, t} \\
& O E_{j, t+1}=a_{0}+a_{1} U E P S_{j, t}+a_{2} A D J_{j, t}+a_{3} N C P L_{j, t}+a_{4} A D J_{j, t} * N C P L_{j, t}+a_{5} \operatorname{Loss}_{j, t}+ \\
& a_{6} A D J_{j, t} * \operatorname{Loss}_{j, t} * N C P L_{j, t}+a_{7} \text { Controls }_{j, t}+v_{j, t} \\
& O E_{j, \Sigma t+1 t o 2}=a_{0}+a_{1} U E P S_{j, t}+a_{2} A D J_{j, t}+a_{3} N C P L_{j, t}+a_{4} A D J_{j, t} * N C P L_{j, t}+a_{5} \text { Controls }_{j, t} \\
& +v_{j, t}
\end{aligned}
$$

This paper tests the $\mathrm{H} 2 \mathrm{~b}$ using two sub-samples (i.e., ASIC compliance firms versus ASIC non-compliance firms) applying the following two equations:

$$
\begin{aligned}
& O E_{j, t+1}=a_{0}+a_{1} \operatorname{UEPS}_{j, t}+a_{2} \text { IndAD }_{j, t}+a_{3} \text { Controls }_{j, t}+v_{j, t} \\
& O E_{j, \sum t+1 t o 2}=a_{0}+a_{1} \operatorname{UEPS}_{j, t}+a_{2} \text { IndAD }_{j, t}+a_{3} \text { Controls }_{j, t}+v_{j, t}
\end{aligned}
$$


Where $\mathrm{j}$ is firm-year observations, and $\mathrm{t}$ is years from 2011 to $2014 . \mathrm{OE}_{\mathrm{j}, t+1}$ is the oneyear-ahead operating earnings ${ }^{2}$ and $\mathrm{OE}_{\mathrm{j}, \Sigma \mathrm{t}+1 \text { to } 2}$ is the sum of two-years-ahead operating earnings, scaled by total assets at the beginning of year $t$. UEPS $\mathrm{j}_{\mathrm{j}, \mathrm{t}}$ is the actual non-IFRS earnings figures that firms report divided by the number of shares outstanding for firm $\mathrm{j}$, in year t. NCPL $\mathrm{N}_{\mathrm{j}, \mathrm{t}}$ is the dummy variable that equals 1 if firm $\mathrm{j}$ does not comply with ASIC guidelines to report non-IFRS earnings in year $t$, and 0 otherwise. ADJ $_{\mathrm{j}, \mathrm{t}}$ is the total actual income-increasing non-IFRS earnings adjustments divided by the number of shares outstanding for firm $\mathrm{j}$, in year $\mathrm{t}$. It is calculated as the actual non-IFRS earnings figures minus the IFRS earnings figures divided by the number of shares outstanding for firm $\mathrm{j}$, in year $\mathrm{t}$. We keep positive $A D J_{\mathrm{j}, \mathrm{t}}$ and set negative $A D J_{\mathrm{j}, \mathrm{t}}$ as $0 . \mathrm{ADJ}_{\mathrm{j}, \mathrm{t}} * \mathrm{NCPL}_{\mathrm{j}, \mathrm{t}}$ is the interaction term between $\mathrm{ADJ}_{\mathrm{j}, \mathrm{t}}$ and $\mathrm{NCPL}_{\mathrm{j}, \mathrm{t}}$. Miss $\mathrm{j}_{\mathrm{j}, \mathrm{t}}$ is a dummy variable that equals 1 if firm $\mathrm{j}$ 's earnings before tax in year $\mathrm{t}$ are less than earnings before tax in year $\mathrm{t}-1$, and zero otherwise. $\operatorname{Loss}_{\mathrm{j}, \mathrm{t}}$ is a dummy variable that equals 1 if firm $\mathrm{j}$ made IFRS losses in year $\mathrm{t}$, and zero otherwise. $\mathrm{ADJ}_{\mathrm{j}, \mathrm{t}} * \mathrm{Miss}_{\mathrm{j}, \mathrm{t}}{ }^{*} \mathrm{NCPL}_{\mathrm{j}, \mathrm{t}}$ is the interaction term between $\operatorname{ADJ}_{\mathrm{j}, \mathrm{t}}, \mathrm{Miss}_{\mathrm{j}, \mathrm{t}}$, and $\mathrm{NCPL}_{\mathrm{j}, \mathrm{t}} \cdot \mathrm{ADJ}_{\mathrm{j}, \mathrm{t}} \operatorname{Loss}_{\mathrm{j}, \mathrm{t}} * \mathrm{NCPL}_{\mathrm{j}, \mathrm{t}}$ is the interaction term between $\mathrm{ADJ}_{\mathrm{j}, \mathrm{t}}$ Loss $_{\mathrm{j}, \mathrm{t}}$, and $\mathrm{NCPL} \mathrm{L}_{\mathrm{j}, \mathrm{t}}$.

IndADJ $_{\mathrm{j}, \mathrm{t}}$ represents eight individual income-increasing non-IFRS earnings adjustments (i.e. different expenses) that are excluded by managers. The eight individual adjustments are presented here. $\mathrm{IA}_{\mathrm{j}, \mathrm{t}}$ is the actual impairment of assets figures divided by the number of shares outstanding for firm $\mathrm{j}$, in year $\mathrm{t}$, for those firms that do not exclude impairment of assets, coded as $0 . \mathrm{LA}_{\mathrm{j}, \mathrm{t}}$ is the actual losses on asset

\footnotetext{
${ }^{2}$ Doyle et al. (2003) use future cash flows as dependent variables. However, this dependent variable is less accurate in evaluating the persistence of adjustments because current liabilities have implications for future cash flows (Kolev et al., 2008). Future earnings before tax as a dependent variable is also less desirable because earnings before tax often includes expenses that are excluded from non-GAAP profit, resulting in a systematic relationship that does not reflect opportunism (Frankel et al., 2011).
} 
dispositions or investment figures divided by the number of shares outstanding for firm $\mathrm{j}$, in year $\mathrm{t}$, for those firms that do not exclude losses on asset dispositions or investments, coded as $0 . \mathrm{RC}_{\mathrm{j}, \mathrm{t}}$ is the actual redundancies and/or restructuring costs divided by the number of shares outstanding for firm $\mathrm{j}$, in year $\mathrm{t}$, for those firms that do not exclude redundancies or restructuring costs, coded as $0 . \mathrm{MAC}_{\mathrm{j}, \mathrm{t}}$ is the actual asset merge or demerge and acquisition-transaction costs divided by the number of shares outstanding for firm $\mathrm{j}$, in year $\mathrm{t}$, for those that firms do not exclude asset merge or demerge and acquisition-transaction costs, coded as $0 . \mathrm{TI}_{\mathrm{j}, \mathrm{t}}$ is the actual figures of expenses related to tax or interest effects divided by the number of shares outstanding for firm $\mathrm{j}$, in year $\mathrm{t}$, for those firms that do not exclude expenses related to tax or interest effects, coded as $0 . \mathrm{FL}_{\mathrm{j}, \mathrm{t}}$ is the actual losses on foreign exchange divided by the number of shares outstanding for firm $\mathrm{j}$, in year $\mathrm{t}$, for those firms that do not exclude losses on foreign exchange, coded as 0 . Equity $\mathrm{j}_{\mathrm{j}, \mathrm{t}}$ is the actual figures of charges or costs on equity accounting divided by the number of shares outstanding for firm $j$, in year $t$, for those firms that do not exclude charges or costs on equity accounting, coded as 0. For compliance firms, Other $\mathrm{j}_{\mathrm{j}, \mathrm{t}}$ includes the costs (e.g., legal costs, Australasia insurance costs, guarantee and commitment fees, losses of natural disasters) that are not classified in any of the seven specific categories mentioned above. For non-compliance firms, Other $_{\mathrm{j}, \mathrm{t}}$ is more ambiguous because the firms do not state what the other expenses are; therefore, we measure Other $_{\mathrm{j}, \mathrm{t}}$ for non-compliance firms as the total income-increasing exclusions minus any of the other seven individual adjustments divided by the number of shares outstanding for firm $\mathrm{j}$, in year $\mathrm{t}$; for those firms that do not present any adjustments, Other $_{\mathrm{j}, \mathrm{t}}$ equals the total income-increasing adjustments divided by the number of shares outstanding for firm $\mathrm{j}$, in year $\mathrm{t}$. 


\subsection{Control Variables for $\mathrm{H} 1$ and $H 2$}

Several control variables from the findings of previous studies are included in the tests. Leverage $\mathrm{j}_{\mathrm{j}, \mathrm{t}}$ is measured by short-term and long-term debt divided by total assets for firm j, in year t (e.g., DeFond and Jiambalvo, 1994; Doukakis, 2014; Francis and Wang, 2008). Firm growth is measured by the market-to-book ratio $\left(\mathrm{MtoB}_{\mathrm{j}, \mathrm{t}}\right)$ and sales growth (SalesG $\mathrm{G}_{\mathrm{j}, \mathrm{t}}$ ) (e.g., Lougee and Marquardt, 2004; Doyle et al., 2013; Black et al., 2017; Zang, 2012). In that, MtoB $_{\mathrm{j}, \mathrm{t}}$ is measured by the market value of equity divided by the book value of equity for firm $j$, in year $t$. Sales $G_{j, t}$ is measured by sales for firm $\mathrm{j}$, in year $\mathrm{t}$, minus the sales for firm $\mathrm{j}$, in year $\mathrm{t}-1$. This result is then divided by the sales for firm $\mathrm{j}$, in year $\mathrm{t}$. Firm profitability is measured by return on equity $\left(\mathrm{ROE}_{\mathrm{j}, \mathrm{t}}\right)$ (e.g., Doyle et al., 2007a; Doyle et al., 2013; Frankel et al., 2011; Doukakis, 2014). The capital intensity $\left(\mathrm{Capital}_{\mathrm{j}, \mathrm{t}}\right)$ measurement is calculated by the ratio of the net book value of property, plant, and equipment to total assets for firm j, in year t (e.g., Baginski et al., 1999; Francis et al., 2004). This study also includes net operating assets at the beginning of the year as a control variable because previous net operating assets, which indicate balance-sheet constraints, influence current managers' decisions to use earnings management (Badertscher, 2011). Net operating assets $\left(\mathrm{NOA}_{\mathrm{j}, \mathrm{t}}\right)$ is measured by shareholders' equity less cash, and cash equivalent, plus total debt divided by lagged sales for firm $\mathrm{j}$, at the beginning of the year $\mathrm{t}$. Firm size $\left(\operatorname{Size}_{\mathrm{j}, \mathrm{t}}\right)$ is measured by the natural logarithm of total assets for firm $\mathrm{j}$, at the beginning of year $\mathrm{t}$ (Ettredge et al., 2005; Doukakis, 2014). Following previous studies (e.g., Lougee and Marquardt, 2004; DeFond and Hung, 2003; Dichev and Tang, 2008; Frankel et al., 2011), we also included earnings variability $\left(\mathrm{SDE}_{\mathrm{j}, \mathrm{t}}\right)$ as a control variable, and measure it as the standard deviation of earnings before tax using a five-year rolling window ending in 
2014 for firm $\mathrm{j} .{ }^{3}$ This paper includes time and industry effects to control the unobservable confounding variables that differ from time to time but are constant across industries, as well as unobservable confounding variables that differ across industries but are constant over time.

\subsection{Testing Value Relevance of Non-IFRS earnings (H3)}

A frequently used model in value-relevance literature is the model of residualincome valuation developed by Ohlson (1995) and refined by Feltham and Ohlson $(1995,1996)$. This model links the market values of the equity of a firm to its abnormal earnings, net book values, and other information (Barth et al., 2001; Holthausen and Watts, 2001). This paper uses Ohlson's (1995) model to test H3 as follows:

$$
\begin{aligned}
& \text { Stock }_{j, t}=a_{0}+a_{1} U E P S_{j, t}+a_{2} N C P L_{j, t}+a_{3} U E P S_{j, t}{ }^{*} N C P L_{j, t}+a_{4} B V E P S_{j, t}+ \\
& a_{5} \text { Controls }_{j, t}+e_{j, t} \\
& \text { Stock }_{j, t}=a_{0}+a_{1} \text { UEPS }_{j, t}+a_{2} N C P L_{j, t}+a_{3} \operatorname{UEPS}_{j, t} * N C P L_{j, t}+a_{4} \text { Miss }_{j, t}+ \\
& a_{5} \operatorname{UEPS}_{j, t} * \text { Miss }_{j, t} * N C P L_{j, t}+a_{6} \text { BVEPS }_{j, t}+a_{7} \text { Controls }_{j, t}+e_{j, t} \\
& \text { Stock }_{j, t}=a_{0}+a_{1} \text { UEPS }_{j, t}+a_{2} N C P L_{j, t}+a_{3} U E P S_{j, t} * N C P L_{j, t}+a_{4} \operatorname{Loss}_{j, t}+ \\
& a_{5} \operatorname{UEPS}_{j, t} * \operatorname{Loss}_{j, t} * N C P L_{j, t}+a_{6} \text { BVEPS }_{j, t}+a_{7} \text { Controls }_{j, t}+e_{j, t}
\end{aligned}
$$

Where $\mathrm{j}$ is firm-year observations, and $\mathrm{t}$ is the years from 2011 to 2014 . Stock $\mathrm{j}_{\mathrm{j}, \mathrm{t}}$ is the stock price for firm $\mathrm{j}$, in year $\mathrm{t}$, on the date of the earnings announcement. $\mathrm{UEPS}_{\mathrm{j}, \mathrm{t}}$ is the actual non-IFRS earnings figures for firm $j$, in year $t . \mathrm{NCPL}_{\mathrm{j}, \mathrm{t}}$ is a dummy variable that equals 1 if firm $\mathrm{j}$ does not comply with ASIC guidelines in reporting non-IFRS earnings in year $\mathrm{t}$, and 0 otherwise. $\mathrm{UEPS}_{\mathrm{j}, \mathrm{t}} * \mathrm{NCPL}_{\mathrm{j}, \mathrm{t}}$ is an interaction term between $\mathrm{UEPS}_{\mathrm{j}, \mathrm{t}}$ and

\footnotetext{
${ }^{3}$ This is a five-year rolling window for each firm, ending in 2014. Specifically, obtaining the data of SDE $E_{j, t}$ in 2011 requires data of earnings before tax from 2007 to 2011; obtaining data of $\mathrm{SDE}_{\mathrm{j}, \mathrm{t}}$ in 2012 requires data of earnings before tax from 2008 to 2012. The same rolling process has been applied for other years and ends in 2014 for firm j.
} 
$\mathrm{NCPL}_{\mathrm{j}, \mathrm{t}} \cdot$ BVEPS $_{\mathrm{j}, \mathrm{t}}$ is the book value divided by the number of shares outstanding for firm $\mathrm{j}$, in year $\mathrm{t}$. Miss $_{\mathrm{j}, \mathrm{t}}$ is a dummy variable that equals 1 if firm $\mathrm{j}$ 's earnings before tax in year $\mathrm{t}$ are less than earnings before tax in year $\mathrm{t}-1$, and zero otherwise. $\operatorname{Loss}_{\mathrm{j}, \mathrm{t}}$ is a dummy variable that equals 1 if firm $\mathrm{j}$ made IFRS losses in year $\mathrm{t}$, and zero otherwise. $\mathrm{UEPS}_{\mathrm{j}, \mathrm{t}} * \mathrm{Miss}_{\mathrm{j}, \mathrm{t}}{ }^{*} \mathrm{NCPL}_{\mathrm{j}, \mathrm{t}}$ is the interaction term between $\mathrm{UEPS}_{\mathrm{j}, \mathrm{t}}$, Miss $\mathrm{j}, \mathrm{t}$, and $\mathrm{NCPL}_{\mathrm{j}, \mathrm{t}}$ $\mathrm{UEPS}_{\mathrm{j}, \mathrm{t}}{ }^{*} \operatorname{Loss}_{\mathrm{j}, \mathrm{t}}{ }^{*} \mathrm{NCPL}_{\mathrm{j}, \mathrm{t}}$ is the interaction term between $\mathrm{UEPS}_{\mathrm{j}, \mathrm{t}}, \operatorname{Loss}_{\mathrm{j}, \mathrm{t}}$, and NCPL $\mathrm{j}, \mathrm{t}$. For equations (3b) and (3c), we only include observations where firms exclude incomeincreasing non-IFRS earnings adjustments, as we are also interested in investigating the value relevance of non-IFRS earnings under opportunistic reporting. Equation (3) also includes the time and industry effects to control the unobservable confounding variables that differ from time to time but are constant across the industries, as well as the unobservable confounding variables that differ across industries but are constant over time.

\section{Empirical Results}

\subsection{Descriptive Statistics of Variables for the Sample}

Table 2 presents the summary statistics of the variables for the hypotheses. Panel A of Table 2 presents the descriptive statistics of the variables for non-IFRS earnings reporting. We present the descriptive statistics for two sub-samples for comparison: the firm-year observations of the firms that do not comply with ASIC guidelines (i.e., non-compliance firms) and the firm-year observations of the firms that comply with ASIC guidelines (i.e., compliance firms).

Non-compliance firms reported higher non-IFRS earnings figures compared with compliance firms $(\mathrm{t}=2.021, \mathrm{p}$-value $=0.044)$. The mean of stock price $\left(\mathrm{Stock}_{\mathrm{j}, \mathrm{t}}\right)$ is 
lower for ASIC non-compliance firms than for ASIC compliance firms $(t=-1.780$, $p$ value $=0.076)$. Compared with ASIC compliance firms, ASIC non-compliance firms are those with a lower market-to-book ratio $(\mathrm{t}=-1.896$, $\mathrm{p}$-value $=0.059)$, with higher rates of sales growth $(\mathrm{t}=2.899, \mathrm{p}$-value $=0.004)$, with a smaller firm size $(\mathrm{t}=-4.813, \mathrm{p}$ value $=0.000)$, with higher leverage ratios $(\mathrm{t}=1.930, \mathrm{p}$-value $=0.054)$, with lower returns on equity $(\mathrm{t}=-2.713$, $\mathrm{p}$-value $=0.007)$, with higher previous-year operating net assets $(\mathrm{t}=2.167, \mathrm{p}=0.031)$, with less intensive capital $(\mathrm{t}=-2.375, \mathrm{p}=0.018)$, and with higher earnings variability $(\mathrm{t}=2.693, \mathrm{p}$-value $=0.008)$.

Panel B of Table 2 presents the descriptive statistics of variables for incomeincreasing non-IFRS earnings adjustments. Compared with ASIC compliance firms, ASIC non-compliance firms present more total adjustments $(\mathrm{t}=2.017, \mathrm{p}$-value $=0.044)$. Examining individual adjustments, ASIC non-compliance firms excluded more expenses related to tax or interest effects $(t=1.687$, $\mathrm{p}$-value $=0.093)$, losses on foreign exchange $(\mathrm{t}=1.870, \mathrm{p}$-value $=0.065)$, charges or costs on equity accounting $(\mathrm{t}=2.261$, $\mathrm{p}$-value $=0.027)$, and other unspecific adjustments $(\mathrm{t}=6.833, \mathrm{p}$-value $=0.000)$, while ASIC compliance firms excluded more losses on asset dispositions or investments $(t=$ $1.799, \mathrm{p}$-value $=0.075)$ and on redundancies or restructuring costs $(\mathrm{t}=-1.713$, $\mathrm{p}$ value $=0.088)$.

$<$ Insert Table 2 about here $>$

\subsection{Pearson and Spearman Correlations}

Given that multicollinearity between variables is a potential concern in multivariate analysis, this study employs Pearson and Spearman correlations for the variables of interest and control variables of the sample, as presented in Table 3. 
Panel A of Table 3 presents the Pearson and Spearman correlations for the variables of non-IFRS earnings reporting, with the results demonstrating that $\mathrm{ADJ}_{\mathrm{j}, \mathrm{t}}$ is positively correlated to Miss $\mathrm{j}_{\mathrm{j}, \mathrm{t}}$ and positively correlated to $\operatorname{Loss}_{\mathrm{j}, \mathrm{t}}$ under the Spearman and Pearson correlations. These findings suggest that when IFRS earnings fail to meet IFRS earnings targets or firms make current IFRS losses, they use income-increasing non-IFRS earnings adjustments to make non-IFRS earnings more profitable. Panel B of Table 3 presents the Pearson and Spearman correlations for the variables of incomeincreasing exclusions. As presented in Panel B of Table 3, most of the individual income-increasing adjustments and total income-increasing adjustments positively correlate with each other under the Pearson and Spearman correlations.

Previous research argues that multicollinearity becomes a serious problem when correlations exceed 0.8 (e.g., Li and Mangena, 2014; Haniffa and Cooke, 2005). The correlation of each variable here is less than 0.8 , suggesting that multicollinearity is not a major problem for the variables in this study. We also consider variance inflation factors (VIF) to determine whether there are any multicollinearity issues in addition to using correlations. The results demonstrate that none of the VIFs are greater than 3 . The results are presented in the notes of the tables presenting the regression results.

$<$ Insert Table 3 about here $>$

\subsection{Results for $\mathrm{HI}$}

Table 4 presents the regression results for $\mathrm{H} 1$ analyzed using the time-industry fixed-effects ordinary least squares (OLS) model. The results demonstrate that $\mathrm{ADJ}_{\mathrm{j}, \mathrm{t}}$ is negatively but statistically insignificantly related to $\operatorname{Miss}_{\mathrm{j}, \mathrm{t}}($ coefficient $=-0.050$, $\mathrm{t}$ value $=-0.550)$ and $\operatorname{Loss}_{\mathrm{j}, \mathrm{t}}($ coefficient $=-0.176, \mathrm{t}$-value $=-1.190)$, suggesting that for 
ASIC compliance firms (i.e., NCPL $=0$ ), even if firms do not meet their earnings targets or make losses, managers do not use income-increasing non-IFRS earnings adjustments to report non-IFRS earnings as higher than current IFRS earnings. $\mathrm{ADJ}_{\mathrm{j}, \mathrm{t}}$ is significantly and positively associated with $\operatorname{Miss}_{\mathrm{j}, \mathrm{t}}{ }^{*} \mathrm{NCPL}_{\mathrm{j}, \mathrm{t}}$ (coefficient $=0.223$, $\mathrm{t}$ value $=1.800)$ and $\operatorname{Loss}_{\mathrm{j}, \mathrm{t}} * \mathrm{NCPL}_{\mathrm{j}, \mathrm{t}}($ coefficient $=0.938, \mathrm{t}$-value $=8.750)$, suggesting that for ASIC non-compliance firms, if firms miss their earnings targets or make losses, managers exclude expenses to achieve greater income-increasing non-IFRS earnings adjustments than do compliance firms to report non-IFRS earnings as higher than the current IFRS earnings.

The results for the control variables indicate that less mature $\left(\mathrm{Capital}_{\mathrm{j}, \mathrm{t}}\right.$, coefficient $=-0.071, \quad t-v a l u e=-1.770)$, less profitable firms $\left(\mathrm{ROE}_{\mathrm{j}, \mathrm{t}}\right.$, coefficient $=-$ 0.371, $\mathrm{t}$-value $=-3.650$ ) make income-increasing adjustments using expenses to arrive at non-IFRS earnings. This behavior may be attributed to the fact that the growth of less mature, less profitable firms lags behind the growth of their more mature competitors, and that these firms feel the need to manage earnings perceptions using incomeincreasing adjustments.

$<$ Insert Table 4 about here $>$

\subsection{Results for $\mathrm{H} 2$}

Table 5 presents the results for the persistence of income-increasing non-IFRS earnings adjustments (H2a) using time-industry fixed-effects OLS regression. The first, second, and third models that tested $\mathrm{H} 2 \mathrm{a}$ present the results with $\mathrm{OE}_{\mathrm{j}, \mathrm{t}+1}$ as the dependent variable. The fourth, fifth, and sixth models that tested H2a present the results with $\mathrm{OE}_{\mathrm{j}, \Sigma \mathrm{t}+1 \text { to2 }}$ as the dependent variable. 
The results demonstrate that $\mathrm{ADJ}_{\mathrm{j}, \mathrm{t}}$ is not significantly associated with $\mathrm{OE}_{\mathrm{j}, \mathrm{t}+1}$ nor

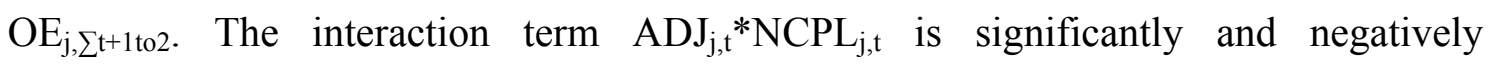
associated with $\mathrm{OE}_{\mathrm{j}, \mathrm{t}+1}($ coefficient $=-0.256$, $\mathrm{t}$-value $=-3.040)$ in the first model and to $\mathrm{OE}_{\mathrm{j}, \Sigma \mathrm{t}+1 \mathrm{to} 2}($ coefficient $=-0.598, \mathrm{t}$-value $=-2.910)$ in the fourth model, suggesting one dollar of expense included in the total income-increasing non-IFRS earnings adjustments by non-compliance firms implies one-year-ahead operating expenses of $\mathrm{A} \$ 0.261$ (i.e., coefficient of $\mathrm{ADJ}_{\mathrm{j}, \mathrm{t}} \mathrm{NCPL}_{\mathrm{j}, \mathrm{t}}$ on $\mathrm{OE}_{\mathrm{j}, \mathrm{t}+1}[-0.256]$ plus coefficient of $\mathrm{ADJ}_{\mathrm{j}, \mathrm{t}}$ on $\left.\mathrm{OE}_{\mathrm{j}, \mathrm{t}+1}[-0.005]\right)$ and future operating expenses over the subsequent two years of $\mathrm{A} \$ 0.599$ (i.e., coefficient of $\mathrm{ADJ}_{\mathrm{j}, \mathrm{t}} * \mathrm{NCPL}_{\mathrm{j}, \mathrm{t}}$ on $\mathrm{OE}_{\mathrm{j}, \Sigma \mathrm{t}+1 \mathrm{to2}}[-0.598]$ plus coefficient of $\mathrm{ADJ}_{\mathrm{j}, \mathrm{t}}$ on $\left.\mathrm{OE}_{\mathrm{j}, \mathrm{Lt}+1 \mathrm{to2}}[-0.001]\right)$. The results for the relationship between $\mathrm{ADJ}_{\mathrm{j}, \mathrm{t}} * \mathrm{NCPL}_{\mathrm{j}, \mathrm{t}}$ and future operating earnings (i.e., $\mathrm{OE}_{\mathrm{j}, \mathrm{t}+1}$ and $\mathrm{OE}_{\mathrm{j}, \Sigma_{\mathrm{t}}+1 \mathrm{to} 2}$ ) for the other models are similar to the results for the first and fourth models, as described above.

The results also show that $\mathrm{ADJ}_{\mathrm{j}, \mathrm{t}}$ * Miss $_{\mathrm{j}, \mathrm{t}}$ *NCPL $\mathrm{L}_{\mathrm{j}, \mathrm{t}}$ is significantly and negatively related to $\mathrm{OE}_{\mathrm{j}, \mathrm{t}+1}($ coefficient $=-0.016, \mathrm{t}$-value $=-3.980)$ in the second model and to $\mathrm{OE}_{\mathrm{j}, \Sigma \mathrm{t}+1 \mathrm{to2}} \quad($ coefficient $=-0.060, \quad \mathrm{t}$-value $=-3.270) \quad$ in $\quad$ the fifth model. $\mathrm{ADJ}_{\mathrm{j}, \mathrm{t}}{ }^{*} \operatorname{Loss}_{\mathrm{j}, \mathrm{t}}$ *NCPL $\mathrm{j}_{\mathrm{j}, \mathrm{t}}$ is significantly and negatively related to $\mathrm{OE}_{\mathrm{j}, \mathrm{t}+1}$ (coefficient $=$ $-0.096, t$ value $=-2.180)$ in the third model and to $\mathrm{OE}_{\mathrm{j}, \sum \mathrm{t}+1 \mathrm{to} 2}($ coefficient $=-0.103, t$ value $=-3.020)$ in the sixth model that are both used to test $\mathrm{H} 2 \mathrm{a}$. The results indicate that when non-compliance firms include one dollar of expense in the total incomeincreasing non-IFRS earnings adjustments, the one-year-ahead operating expenses and future operating expenses over the subsequent two years of firms that miss the IFRS earnings target would exceed that of firms that meet the IFRS earnings target by A $\$ 0.016$ and $A \$ 0.06$, respectively. Further, on such inclusion of one dollar of expense, the one-year-ahead operating expenses and future operating expenses over the 
subsequent two years of non-compliance firms that incur IFRS losses would exceed that of non-compliance firms that earn IFRS profits by A $\$ 0.096$ and A $\$ 0.103$, respectively.

Collectively, the results presented in Table 5 indicate that the income-increasing non-IFRS earnings adjustments excluded by non-compliance firms are persistent into future earnings, suggesting that the income-increasing adjustments made by noncompliance firms are not one-off items.

$<$ Insert Table 5 about here $>$

Table 6 presents the results for $\mathrm{H} 2 \mathrm{~b}$ using eight individual adjustments as the independent variables. To test $\mathrm{H} 2 \mathrm{~b}$, we examine two sub-samples to understand how reported individual income-increasing adjustments differ between compliance firms and non-compliance firms. The first and second models in testing $\mathrm{H} 2 \mathrm{~b}$ present the results for $\mathrm{H} 2 \mathrm{~b}$ using eight individual income-increasing adjustments as independent variables and future operating earnings as the dependent variables for a sample of non-compliance firms, while we also present the results for $\mathrm{H} 2 \mathrm{~b}$ using eight individual incomeincreasing adjustments as independent variables and future operating earnings as dependent variables for a sample of compliance firms. The first and second models of Table 6 demonstrate that for the sample of ASIC non-compliance firms, FL $_{\mathrm{j}, \mathrm{t}}$ is weakly significantly and negatively associated with $\mathrm{OE}_{\mathrm{j}, \Sigma \mathrm{t}+1 \mathrm{to2}}(\mathrm{coefficient}=-0.005$, $\mathrm{t}$-value $=-$ 1.810), Equity $\mathrm{j}_{\mathrm{j}, \mathrm{t}}$ is significantly and negatively associated with $\mathrm{OE}_{\mathrm{j}, \mathrm{t}+1}$ (coefficient = 0.017, t-value $=-2.040)$ and with $\mathrm{OE}_{\mathrm{j}, \Sigma \mathrm{t}+1 \mathrm{to2}}($ coefficient $=-0.061, \mathrm{t}$-value $=-2.220)$, Other $_{\mathrm{j}, \mathrm{t}}$ is significantly and negatively associated with $\mathrm{OE}_{\mathrm{j}, \mathrm{t}+1}$ (coefficient $=-0.034$, $\mathrm{t}-$ value $=-3.210)$ and with $\mathrm{OE}_{\mathrm{j}, \Sigma \mathrm{t}+1 \mathrm{to} 2}($ coefficient $=-0.168, \mathrm{p}$-value $=-3.830)$. The results mean that one dollar of expense included in the "losses on foreign exchange" category 
of income-increasing non-IFRS earnings exclusions implies two-year-ahead operating expenses of $\mathrm{A} \$ 0.005$; one dollar of expense included in the category of "charges or costs on equity accounting" of income-increasing non-IFRS earnings exclusions implies one-year-ahead operating expenses of $A \$ 0.017$, and future operating expenses over the subsequent two years of $\mathrm{A} \$ 0.061$; one dollar of expense included in the "other" category of income-increasing non-IFRS earnings exclusions implies one-year-ahead operating expenses of $\mathrm{A} \$ 0.034$, and future operating expenses over the subsequent two years of A $\$ 0.168$. As shown in Table 6, the third and fourth models demonstrate that for firms complying with the ASIC guidelines, none of the individual adjustments is significantly related to future operating earnings except "other". Other $\mathrm{j}_{\mathrm{j}, \mathrm{t}}$ is weakly significantly and negatively associated with $\mathrm{OE}_{\mathrm{j}, \mathrm{t}+1}$ (coefficient $=-0.029, \mathrm{t}$-value $=-$ $1.810)$ and with $\mathrm{OE}_{\mathrm{j}, \Sigma \mathrm{t}+1 \text { to2 }}($ coefficient $=-0.026, \mathrm{t}$-value $=-1.660)$.

The results presented in Table 6 combined with the results presented in Table 5 suggest that ASIC non-compliance firms opportunistically exclude recurring expenses from IFRS earnings and categorize them as "losses on foreign exchange," "charges or costs on equity accounting," and "other" in the non-IFRS earnings calculation schedule to make non-IFRS earnings appear more profitable than IFRS earnings. The category of "other" is particularly ambiguous, which means that its composition is less likely to be detected by investors. Unlike with non-compliance firms, most income-increasing adjustments made by ASIC compliance firms do not persist into future operating earnings, suggesting that ASIC compliance firms disclose non-IFRS earnings faithfully.

$<$ Insert Table 6 about here $>$ 


\subsection{Results for $H 3$}

Table 7 provides the results of the time-industry fixed-effects OLS regressions for value relevance $(\mathrm{H} 3)$. The first model that tested $\mathrm{H} 3$ presents the result demonstrating that $\mathrm{UEPS}_{\mathrm{j}, \mathrm{t}}$ is significantly and positively associated with Stock $_{\mathrm{j}, \mathrm{t}}$ (coefficient $=0.615, \mathrm{t}$-value $=6.230$ ). The first model also finds that $\mathrm{UEPS}_{\mathrm{j}, \mathrm{t}} * \mathrm{NCPL}_{\mathrm{j}, \mathrm{t}}$ is significantly and negatively associated with Stock $_{\mathrm{j}, \mathrm{t}}$ (coefficient $=-0.179, \mathrm{t}$-value $=$ 4.840). The coefficient on non-IFRS earnings is 0.615 for the firm that complies with ASIC guidelines $(\mathrm{NCPL}=0)$, and $0.436(0.615-0.179)$ for the firm that does not comply with ASIC guidelines $(\mathrm{NCPL}=1)$; a decrease of $29 \%$. The results indicate that, on average, the market perceives non-IFRS earnings reported by non-compliance firms as less value relevant than the non-IFRS earnings reported by compliance firms. In the second model that tested $\mathrm{H} 3$, on limiting the sample to the observations where the firms applied income-increasing non-IFRS earnings and introducing Miss $_{\mathrm{j}, \mathrm{t}}$ and $\operatorname{Loss}_{\mathrm{j}, \mathrm{t}}$ with their interaction terms UEPS $\mathrm{j}_{\mathrm{j}, \mathrm{t}} * \mathrm{Miss}_{\mathrm{j}, \mathrm{t}} * \mathrm{NCPL}_{\mathrm{j}, \mathrm{t}}$ and $\mathrm{UEPS}_{\mathrm{j}, \mathrm{t}}{ }^{*} \operatorname{Loss}_{\mathrm{j}, \mathrm{t}} * \mathrm{NCPL}_{\mathrm{j}, \mathrm{t}}$, the results changed as follows: UEPS $_{\mathrm{j}, \mathrm{t}}$ coefficient is significantly and positively associated with Stock $_{\mathrm{j}, \mathrm{t}}($ coefficient $=0.643, \mathrm{t}-\mathrm{value}=6.920) ; \mathrm{UEPS}_{\mathrm{j}, \mathrm{t}}{ }^{*} \mathrm{NCPL}_{\mathrm{j}, \mathrm{t}}$ is not significantly associated with Stock $_{\mathrm{j}, \mathrm{t}}$; and $\mathrm{UEPS}_{\mathrm{j}, \mathrm{t}} * \mathrm{Miss}_{\mathrm{j}, \mathrm{t}} * \mathrm{NCPL}_{\mathrm{j}, \mathrm{t}}$ is significantly and positively associated with Stock $_{\mathrm{j}, \mathrm{t}}($ coefficient $=0.122, t$ value $=2.940)$. Similar results have been found in the third model where: UEPS $_{\mathrm{j}, \mathrm{t}}$ coefficient is significantly and positively associated with Stock $_{\mathrm{j}, \mathrm{t}}($ coefficient $=0.631$, $\mathrm{t}$-value $=7.350) ; \mathrm{UEPS}_{\mathrm{j}, \mathrm{t}}{ }^{*} \mathrm{NCPL}_{\mathrm{j}, \mathrm{t}}$ is weakly significantly and negatively associated with Stock $_{\mathrm{j}, \mathrm{t}}($ coefficient $=-0.189, \mathrm{t}$-value $=$ 1.720); UEPS $\mathrm{j}_{\mathrm{j}, \mathrm{t}}$ Miss $_{\mathrm{j}, \mathrm{t}}{ }^{*} \mathrm{NCPL} \mathrm{j}_{\mathrm{j}, \mathrm{t}}$ is significantly and positively associated with Stock $_{\mathrm{j}, \mathrm{t}}$ (coefficient $=0.341, \mathrm{t}$-value $=3.990)$. The results illustrate that when firms miss IFRS earnings target or incur IFRS losses, the application of income-increasing non-IFRS 
earnings adjustments made by non-compliance firms lead investors to believe the nonIFRS earnings are more value relevant than non-IFRS earnings reported by compliance firms.

$$
<\text { Insert Table } 7 \text { about here }>
$$

Studies on countries such as the United States where compliance with reporting standards on non-GAAP earnings is compulsory reveal that compulsory introduction of non-GAAP guidelines can significantly increase the reporting quality of non-GAAP earnings and decreases opportunistic non-GAAP reporting (Bowen et al., 2005) and misleading reporting practices (Entwistle et al., 2006). Further, the probability that firms disclose non-GAAP earnings to meet or beat forecasts declines (Heflin and Hsu, 2008) and confidence in the market increases (Marques, 2006). However, our study finds that although ASIC has issued guidelines to limit firms' opportunistic non-IFRS earnings reporting, following these guidelines is not mandatory for reporting firms. Such reporting is still present in non-compliance firms and investors are misled by these reporting practices into believing that opportunistic non-IFRS earnings are value relevant. 


\section{Additional Tests}

\subsection{The effect of income-decreasing exclusions on future operating earnings}

To address whether income-decreasing non-IFRS earnings adjustments have any effect on future operating earnings, this study conducted an additional test to re-examine H2a by replacing income-increasing non-IFRS earnings adjustments with incomedecreasing non-IFRS earnings adjustments. In particular, DeADJ $\mathrm{j}_{\mathrm{j}, \mathrm{t}}$ represents total actual income-decreasing non-IFRS earnings adjustments divided by the number of shares outstanding for firm $\mathrm{j}$, in year $\mathrm{t}$. It is calculated as the actual non-IFRS earnings figures minus the IFRS earnings figures divided by the number of shares outstanding for firm $\mathrm{j}$, in year t. For this test, we keep negative adjustments and set positive adjustments as 0 , and take the absolute value of income-decreasing non-IFRS earnings adjustments. The results are presented in Table 8 . The analysis demonstrates that $\operatorname{DeADJ}_{\mathrm{j}, \mathrm{t}}$ and $\operatorname{DeADJ}_{\mathrm{j}, \mathrm{t}} * \mathrm{NCPL}_{\mathrm{j}, \mathrm{t}}$ are positively but not significantly associated with future operating earnings. The positive relationship suggests that firms that report nonIFRS earnings as lower than IFRS earnings tend to exclude recurring revenues to make non-IFRS earnings lower than IFRS earnings. However, the relationship is insignificant, which we consider is because of the limited observations (there are only 79 of 407 observations that reported non-IFRS earnings lower than IFRS earnings; seven of 407 observations that reported non-IFRS earnings equal to IFRS earnings). The results of this test provide an avenue for future study to extend the sample size and examine managers' incentives to exclude income-decreasing non-IFRS earnings adjustments and individual income-decreasing non-IFRS earnings adjustments.

$<$ Insert Table 8 about here $>$ 


\subsection{Change of earnings targets}

In this study, current earnings being lower than previous earnings is used as a benchmark for opportunism. There are other benchmarks for opportunism, such as whether the firm is able to achieve a profit with the non-IFRS earnings, when the IFRS earnings as negative. In this section, we re-test our three hypotheses by replacing Miss $_{\mathrm{j} . t}$ with Profit $\mathrm{t}_{\mathrm{j}, \mathrm{t}}$. Profit $\mathrm{j}_{\mathrm{j}, \mathrm{t}}$ is a dummy variable that equals 1 if firm $\mathrm{j}$ achieves a profit with non-IFRS earnings, when IFRS earnings is negative in year $t$, and 0 otherwise. The results, presented in Table 9, are similar to our main results, suggesting that noncompliance firms report non-IFRS earnings opportunistically to convert IFRS losses to non-IFRS profits. Further, the market perceives opportunistic non-IFRS earnings reporting made by non-compliance firms is more value relevant than non-IFRS earnings reported by compliance firms.

$<$ Insert table 9 about here $>$

We acknowledge that meeting analysts' forecasts is also a commonly used benchmark, but compared with their US counterparts, analysts do not follow Australian firms intensively (Habib and Hossain, 2008; Lont et al., 2010). Moreover, we had limited access to forecast data and propose including this benchmark in a future study.

\section{Conclusion}

This paper examines how ASIC non-IFRS earnings reporting guidelines influence the non-IFRS earnings reporting quality in Australian listed firms from 2011 to 2014. Furthermore, the paper examines how the market reacts to the non-IFRS earnings reported by ASIC compliance firms versus its reaction to the non-IFRS 
earnings reported by ASIC non-compliance firms, when there is presence of opportunistic non-IFRS earnings practice.

For ASIC non-compliance firms, this study finds that missing earnings targets or making current losses leads such firms to exclude income-increasing non-IFRS earnings adjustments to report non-IFRS earnings higher than IFRS earnings. In addition, this study finds that the income-increasing non-IFRS earnings adjustments excluded by noncompliance firms are persistent into future operating earnings and that such firms categorize these recurring expenses as "losses on foreign exchange," "charges or costs on equity accounting," and "other expenses". We find that most income-increasing adjustments are non-recurring and unimportant for ASIC compliance firms, suggesting that these firms attempt to act as responsible reporters by signaling non-IFRS earnings in a responsible manner to demonstrate that they use discretion judiciously to inform investors. We also find that the market perceives non-IFRS earnings reported by ASIC non-compliance firms to be more value relevant than the non-IFRS earnings reported by ASIC compliance firms, in the presence of opportunistic non-IFRS earnings reporting.

Three study limitations should be considered when interpreting our results. First, like other empirical research, our results may suffer from endogeneity problems. Although we use models of time-industry effects to control for the unobservable confounding variables that differ from time to time, as well as unobservable confounding variables that differ across industries, we cannot fully control for all other unobservable variables that influence explanatory variables. Second, we investigated only the ASX 200 listed Australian firms. Generalizing these results to other countries requires future research. Third, we focused only on managers' motivation to report 
income-increasing non-IFRS earnings when firms miss earnings targets, make current losses, and convert IFRS losses to non-IFRS profits, and future research could examine other managers' motivation to report income-decreasing non-IFRS earnings adjustments, such as whether firms report income-increasing non-IFRS earnings to meet analyst forecast in Australia. Future research should evaluate the effects of managerial risk undertaken in such reporting or the influence of managers' compensation on the level of non-IFRS earnings reporting. We propose that future research should also examine whether managers' incentives affect when and how they report non-IFRS earnings.

The findings of this paper enrich the literature on current voluntary disclosure in non-IFRS earnings reporting in a voluntary-reporting setting and pave the way to update financial-reporting policies using empirical evidence related to non-IFRS earnings reporting. Compared with the findings in the countries where compliance with nonGAAP earnings is compulsory (e.g., the US), which generally suggest that compulsory introduction of non-GAAP guidelines can increase the quality of non-GAAP earnings reporting (see Bowen et al., 2005; Entwistle et al., 2006; Heflin and Hsu, 2008; Marques, 2006), our study finds that although ASIC has issued guidelines to limit firms' opportunistic non-IFRS earnings reporting, following these guidelines is voluntary for reporting firms. Opportunistic non-IFRS earnings reporting is still present in non-compliance firms and investors are misled by such reporting practices into believing that opportunistic non-IFRS earnings are value relevant. Hence, regulators should consider the practices of these firms when designing policies related to reporting non-IFRS earnings. We suggest mandatorily enforcing the guidelines on non-IFRS earnings reporting firms to mitigate such opportunistic reporting. When possible, ASIC 
should increase its enforcement action against firms that do not comply with these guidelines. Our findings would help the government in undertaking law reforms to ensure that firms that do not comply with ASIC guidelines do so or face legal action if they provide misleading information. 


\section{References}

Albring, S. M., M. T. Cabán-García and J. L. Reck, "The value relevance of a non-GAAP performance metric to the capital markets," Review of Accounting and Finance 9.3 (2010), pp. 264-284.

ASIC (Australian Securities and Investments Commission) Disclosing financial information other than in accordance with accounting standards (2011a), March, ASIC, Australia.

ASIC (Australian Securities and Investments Commission) Regulatory Guide 230: Disclosing non-IFRS financial information (2011b), December, ASIC, Australia.

Badertscher, B., "Overvaluation and the choice of Alternative earnings management mechanisms," The Accounting Review 86.5 (2011), pp. 1491-1518.

Badertscher, B., D. Collins and T. Lys, "Discretionary accounting choices and the predictive ability of accruals with respect to future cash flows," Journal of Accounting and Economics 52. 1-2 (2012), pp. 330-352.

Baginski, S., K. Lorek, G. L. Willinger and B. Branson, "The relationship between economic characteristics and alternative annual earnings persistence measures," The Accounting Review 74. 1 (1999), pp. 105-120.

Barth, M. E., W. H. Beaver and W. R. Landsman, "The relevance of the value relevance literature for financial accounting standard setting: another view," Journal of Accounting and Economics 31. 1 (2001), pp. 77-104.

Barth, M., I. Gow and D. Taylor, "Why do non-GAAP and Street earnings not reflect changes in GAAP? Evidence from SFAS 123R," Review of Accounting Studies 17. 3 (2012), pp. 526-62.

Bhattacharya, N., E. L. Black, T. E. Christensen and C. R. Larson, "Assessing the relative informativeness and permanence of non-GAAP earnings and GAAP operating earnings," Journal of Accounting and Economics 36. 1-3 (2003), pp. 285-319.

Bhattacharya, N., E. L. Black, T. E. Christensen and R. D. Mergenthaler, "Empirical Evidence on Recent Trends in Non-GAAP Reporting," Accounting Horizons 18. 1 (2004), pp. 27-43. 
Black, D. E. and T. E. Christensen, 'US Managers' Use of 'Non-GAAP' Adjustments to Meet Strategic Earnings Targets," Journal of Business Finance and Accounting 36. 3-4 (2009), pp. 297-326.

Black, D. E., E. L. Black, T. E. Christensen and W. G. Heninger, "Has the Regulation of Non-GAAP Reporting in the US Changed Investors' Perceptions of Non-GAAP Earnings Disclosures?" Journal of Business Finance and Accounting 39. 7-8 (2012), pp. 876-904.

Black, E. L., T. E. Christensen, T. T. Joo and R. Schmardebeck, "The relation between earnings management and non-GAAP reporting," Contemporary Accounting Research 34. 2 (2017), pp. 750-782.

Bowen, R. M., A. K. Davis and D. A. Matsumoto, "Emphasis on Non-GAAP versus GAAP Earnings in Quarterly Press Releases: Determinants, SEC Intervention, and Market Reactions," The Accounting Review 80. 4 (2005), pp. 1011-1038.

Bradshaw, M. T. and R. G. Sloan, "GAAP versus The Street: An Empirical Assessment of Two Alternative Definitions of Earnings," Journal of Accounting Research 40. 1 (2002), pp. 41-66.

Brown, L. and K. Sivakumar, "Comparing the Value Relevance of Two Operating Income Measures," Review of Accounting Studies 8.4 (2003), pp. 561-572.

Choi, Y. S., S. Lin, M. Walker and S. Young, "Disagreement over the persistence of earnings components: evidence on the properties of management-specific adjustments to GAAP earnings," Review of Accounting Studies 12.4 (2007), pp. 595-622.

Collins, D., O. Li and H. Xie, "What drives the increased informativeness of earnings announcements over time?" Review of Accounting Studies 14. 1 (2009), pp. 1-30.

Dahmash, F. N., R. B. Durand and J. Watson, "The value relevance and reliability of reported goodwill and identifiable intangible assets," The British Accounting Review 41. 2 (2009), pp. 120-137.

DeFond, M. L. and J. Jiambalvo, "Debt covenant violation and manipulation of accruals," Journal of Accounting and Economics 17. 1-2 (1994), pp. 145-176.

DeFond, M. L., and M. Hung, “An Empirical Analysis of Analysts' Cash Flow Forecasts," Journal of Accounting and Economics 35.1 (2003), 73-100.

Deloitte, "Underlying Profit," (2010), Deloitte Touche Tohmatsu. 
Dichev, I. and V. Tang, "Earnings volatility and earnings predictability," Journal of Accounting and Economics 47. 1 (2008), pp. 160-181.

Doukakis, L. C., "The effect of mandatory IFRS adoption on real and accrual-based earnings management activities," Journal of Accounting and Public Policy 33. 6 (2014), pp. 551-572.

Doyle, J., J. Jennings and M. Soliman, "Do mangers define non-GAAP earnings to meet or beat analyst forecasts," Journal of Accounting and Economics 56.1 (2013), pp. 4056.

Doyle, J., R. Lundholm and M. Soliman, "The Predictive Value of Expenses Excluded from Non-GAAP Earnings," Review of Accounting Studies 8. 2-3 (2003), pp. 145-174.

Doyle, J., W. Ge and S. McVay, “Accruals quality and internal control over financial reporting," The Accounting Review 82. 5 (2007a), pp. 1141-1170.

Elshafie, M., A. Yen and M. Yu, "The association between non-GAAP earnings and earnings management," Review of Accounting and Finance 9. 2 (2010), pp.139-155.

Entwistle, G. M., G. D. Feltham and C. Mbagwu, "Financial Reporting Regulation and the Reporting of Non-GAAP Earnings," Accounting Horizons 20. 1 (2006), pp. 39-55.

Ettredge, M., S. Kwon, D. Smith and P. Zarowin, "The impact of SFAS No. 131 business segment data on the market's ability to anticipate future earnings," The Accounting Review 80. 3 (2005), pp. 773-804.

Feltham, J. and J. A. Ohlson, "Uncertainty resolution and the theory of depreciation measurement," Journal of Accounting Research 34. 2 (1996), pp. 209-234.

Feltham, J. and J. A. Ohlson, "Valuation and clean surplus accounting for operating and financial activities," Contemporary Accounting Research 11. 2 (1995), pp. 689-731.

Francis, J. and D. Wang, "The joint effect of investor protection and Big 4 audits on earnings quality around the world," Contemporary Accounting Research 25.1 (2008), pp. 157-191.

Francis, J., R. LaFond, P. M. Olsson and K. Schipper, "Costs of Equity and Earnings Attributes," The Accounting Review 79. 4 (2004), pp. 967-1010.

Frankel, R., S. McVay and M. Soliman, "Non-GAAP earnings and board independence," Review of Accounting Studies 16. 4 (2011), pp. 719-744. 
Habib, A. and M. Hossain, "Do managers manage earnings to 'just meet or beat' analyst forecasts?: Evidence from Australia," Journal of International Accounting, Auditing and Taxation 17. (2008), pp.79-91.

Haniffa, M. R. and T. E. Cooke, "The Impact of Culture and Governance on Corporate Social Reporting," Journal of Accounting and Public Policy 24.5 (2005), pp. 391-430.

Heflin, F. and C. Hsu, "The impact of the SEC's regulation of non-GAAP disclosures," Journal of Accounting and Economics 46. 2-3 (2008), pp. 349-365.

Hitz, J. M., "Information versus strategic reporting: determinants of the disclosure of non-GAAP earnings by large German corporations," (2010), Unpublished working paper, Available at: $\underline{\text { http://ssrn.com/abstract }=1549675}$

Holthausen, R. W. and R. L. Watts, "The relevance of the value-relevance literature for financial accounting standard setting," Journal of Accounting and Economics 31. 1 (2001), pp. 3-75.

Isidro, H. and A. Marques, "The Role of Institutional and Economic Factors in the Strategic Use of Non-GAAP Disclosures to Beat Earnings Benchmarks," European Accounting Review 24. 1 (2014), pp. 1-33.

Johnson, W. B. and W. C. Schwartz, “Are Investors Misled by 'Non-GAAP' Earnings?” Contemporary Accounting Research 22. 4 (2005), pp. 915-963.

Kolev, K., C. Marquardt and S. McVay, "SEC Scrutiny and the Evolution of NonGAAP Reporting”, The Accounting Review 83. 1 (2008), pp. 157-184.

KPMG, “Underlying profits survey report," (2009), KPMG, Australia.

Landsman, W. R., B. L. Miller and S. Yeh, "Implications of Components of Income Excluded from Non-GAAP Earnings for Future Profitability and Equity Valuation," Journal of Business Finance and Accounting 34. 3-4 (2007), pp. 650-675.

Li, J. and M. Mangena, "Capital market pressures and the format of intellectual capital disclosure in intellectual capital intensive firms," Journal of Applied Accounting Research 15. 3 (2014), pp. 339-354.

Lont, D., N. Wong, E. Cheung, E. Evans, and S. Wright, "An historical review of quality in financial reporting in Australia," Pacific Accounting Review 22. (2010), pp.147-169. 
Lougee, B. A. and C. A. Marquardt, "Earnings Informativeness and Strategic Disclosure: An Empirical Examination of 'Non-GAAP' Earnings," The Accounting Review 79. 3 (2004), pp. 769-795.

Marques, A., "SEC interventions and the frequency and usefulness of non-GAAP financial measures," Review of Accounting Studies 11.4 (2006), pp. 549-574.

Ohlson, J., "Earnings, book values and dividends in security valuation," Contemporary Accounting Research 11. 2 (1995), pp. 661-687.

SEC (Securities and Exchange Commission), "Final Rule: Conditions for use of nonGAAP financial measures", (2003), Release Nos. 33-8176; 34-47226; FR-65; FILE NO. S7-43-02. Washington, DC: SEC.

Zang, A., "Evidence on the trade-off between real activities manipulation and accrual based earning management," The Accounting Review 87. 2 (2012), pp. 675-703.

Zhang, H. and L. Zheng, "The valuation impact of reconciling non-GAAP earnings to GAAP earnings," Journal of Accounting and Economics 51. 1-2 (2011), pp. 186-202. 


\section{Tables}

Table 1: Sample selection

\begin{tabular}{|l|l|l|}
\hline Sample selection & Number of firms & Firm-year observations \\
\hline Top ASX200 firms & 200 & 800 \\
\hline Exclusions: & & \\
\hline Banks & 6 & 24 \\
\hline Insurance & 4 & 16 \\
\hline Diversified financials & 9 & 36 \\
\hline Real estate & 19 & 76 \\
\hline $\begin{array}{l}\text { Missing data } \\
\text { Final group investigated }\end{array}$ & 10 & 404 \\
\hline $\begin{array}{l}\text { Non-IFRS earnings reporting } \\
\text { voluntarily follow ASIC } \\
\text { guidelines }\end{array}$ & 131 & 608 \\
\hline $\begin{array}{l}\text { Reported non-IFRS earnings } \\
\text { are greater than statutory } \\
\text { adjustments) }\end{array}$ & 110 & 321 \\
\hline $\begin{array}{l}\text { income- } \\
\text { arning non-IFRS earnings }\end{array}$ & 46 & 184 \\
\hline
\end{tabular}

4 This paper has deleted the firms that do not have annual reports over four years. They are Aurizon Holdings Limited; Carsales. Com Limited; Echo Entertainment Group Limited; Maverick Drilling and Exploration Limited; Treasury Wine Estates Limited; Trade Me Group Limited; Macquarie Atlas Roads Group; Alacer Gold Corporation; Myer Holdings Limited; and Dulux Group Limited. 
Table 2: Descriptive statistics for non-IFRS earnings reporting variables

\begin{tabular}{|c|c|c|c|c|c|c|c|c|}
\hline \multirow[b]{2}{*}{ Variables } & \multicolumn{2}{|c|}{$\begin{array}{l}\text { All observations } \\
(\mathrm{N}=407)\end{array}$} & \multicolumn{2}{|c|}{$\begin{array}{l}\text { Non-compliance } \\
(\mathrm{N}=223)\end{array}$} & \multicolumn{2}{|c|}{$\begin{array}{l}\begin{array}{l}\text { Compliance } \\
(\mathrm{N}=184)\end{array} \\
\end{array}$} & \multicolumn{2}{|l|}{ T-test } \\
\hline & Mean & Std. dev & Mean & Std. dev & Mean & Std. dev & $\mathrm{t}$ & p-value \\
\hline Stock $_{\mathrm{j}, \mathrm{t}}$ & 3.295 & 1.091 & 3.209 & 1.162 & 3.399 & 0.991 & $-1.780^{*}$ & 0.076 \\
\hline $\mathrm{UEPS}_{\mathrm{j}, \mathrm{t}}$ & 1.264 & 0.924 & 1.347 & 0.973 & 1.164 & 0.853 & $2.021^{* *}$ & 0.044 \\
\hline MtoB $_{j, t}$ & 2.842 & 2.777 & 2.612 & 3.094 & 3.121 & 2.315 & $-1.896^{*}$ & 0.059 \\
\hline $\mathrm{ROE}_{\mathrm{j}, \mathrm{t}}$ & 0.136 & 0.296 & 0.101 & 0.318 & 0.179 & 0.262 & $-2.713^{* * *}$ & 0.007 \\
\hline $\mathrm{SDE}_{\mathrm{j}, \mathrm{t}}$ & 0.121 & 0.250 & 0.149 & 0.317 & 0.087 & 0.121 & $2.693^{* * *}$ & 0.008 \\
\hline Leverage $_{\mathrm{j}, \mathrm{t}}$ & 0.313 & 0.324 & 0.341 & 0.297 & 0.278 & 0.351 & $1.930^{*}$ & 0.054 \\
\hline $\mathrm{NOA}_{\mathrm{j}, \mathrm{t}}$ & 0.801 & 0.660 & 0.863 & 0.736 & 0.725 & 0.547 & $2.167^{* *}$ & 0.031 \\
\hline $\operatorname{Size}_{\mathrm{j}, \mathrm{t}}$ & 7.663 & 1.626 & 7.325 & 1.702 & 8.072 & 1.429 & $-4.813^{* * *}$ & 0.000 \\
\hline Capital $_{\mathrm{j}, \mathrm{t}}$ & 3.893 & 0.901 & 3.797 & 0.871 & 4.010 & 0.924 & $-2.375^{* *}$ & 0.018 \\
\hline Sales $\mathrm{G}_{\mathrm{j}, \mathrm{t}}$ & 0.119 & 0.275 & 0.154 & 0.283 & 0.076 & 0.259 & $2.899^{* * *}$ & 0.004 \\
\hline
\end{tabular}

\begin{tabular}{|c|c|c|c|c|c|c|c|c|c|c|c|}
\hline \multirow[b]{2}{*}{ Variable } & \multicolumn{3}{|c|}{ Full sample } & \multicolumn{3}{|c|}{ Non-compliance } & \multicolumn{3}{|c|}{ Compliance } & \multicolumn{2}{|l|}{ T-test } \\
\hline & Obs & Mean & Std. Dev. & Obs & Mean & Std. Dev. & Obs & Mean & Std. Dev. & $\mathrm{t}$ & $\mathrm{p}$-value \\
\hline $\mathrm{ADJ}_{\mathrm{j}, \mathrm{t}}$ & 407 & 0.305 & 0.442 & 223 & 0.334 & 0.494 & 184 & 0.248 & 0.365 & $2.017^{* *}$ & 0.044 \\
\hline $\mathrm{IA}_{\mathrm{j}, \mathrm{t}}$ & 204 & 0.125 & 0.293 & 106 & 0.151 & 0.387 & 98 & 0.097 & 0.128 & 1.359 & 0.177 \\
\hline $\mathrm{LA}_{\mathrm{j}, \mathrm{t}}$ & 134 & 0.097 & 0.202 & 63 & 0.063 & 0.246 & 71 & 0.127 & 0.247 & $-1.799^{*}$ & 0.075 \\
\hline $\mathrm{RC}_{\mathrm{j}, \mathrm{t}}$ & 153 & 0.135 & 0.369 & 85 & 0.091 & 0.421 & 68 & 0.189 & 0.284 & $-1.713^{*}$ & 0.088 \\
\hline $\mathrm{MAC}_{\mathrm{j}, \mathrm{t}}$ & 90 & 0.179 & 0.368 & 31 & 0.156 & 0.261 & 59 & 0.192 & 0.415 & -0.503 & 0.616 \\
\hline $\mathrm{TI}_{\mathrm{j}, \mathrm{t}}$ & 154 & 0.049 & 0.248 & 87 & 0.077 & 0.285 & 67 & 0.013 & 0.184 & $1.687^{*}$ & 0.093 \\
\hline $\mathrm{FL}_{\mathrm{j}, \mathrm{t}}$ & 81 & 0.099 & 0.103 & 43 & 0.122 & 0.119 & 38 & 0.079 & 0.087 & $1.870^{*}$ & 0.065 \\
\hline Equity $_{\mathrm{j}, \mathrm{t}}$ & 98 & 0.068 & 0.269 & 61 & 0.107 & 0.326 & 37 & 0.005 & 0.104 & $2.261^{* *}$ & 0.027 \\
\hline Other $_{j, t}$ & 214 & 0.211 & 0.391 & 153 & 0.289 & 0.428 & 61 & 0.016 & 0.156 & $6.833^{* * *}$ & 0.000 \\
\hline
\end{tabular}

Note: ${ }^{*} \mathrm{p}<0.10,{ }^{* *} \mathrm{p}<0.05,{ }^{* * *} \mathrm{p}<0.01$. Variables are defined in Appendix. 
Table 3: Pearson and Spearman correlations for sample variables

Pearson 』

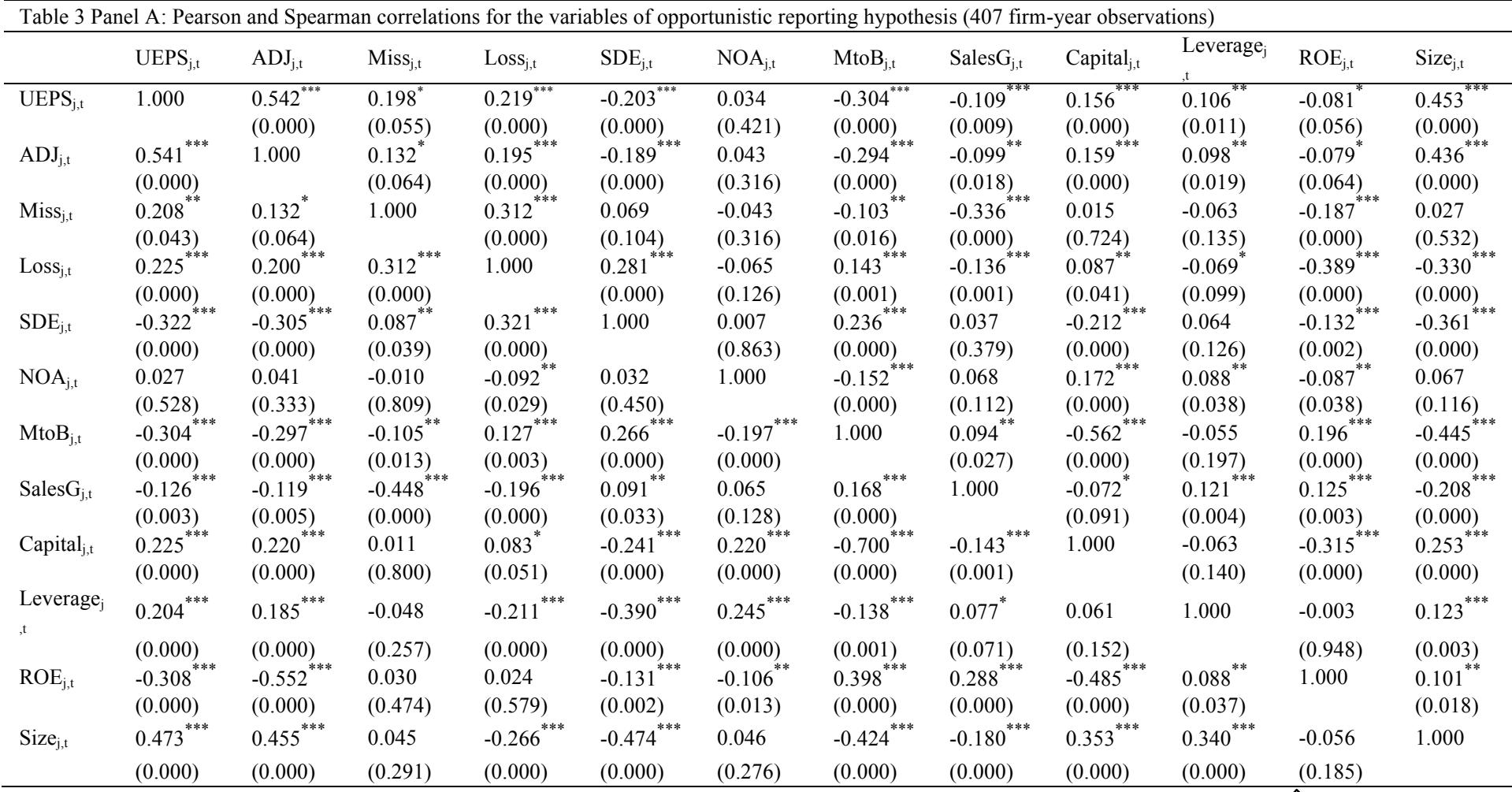

Pearson

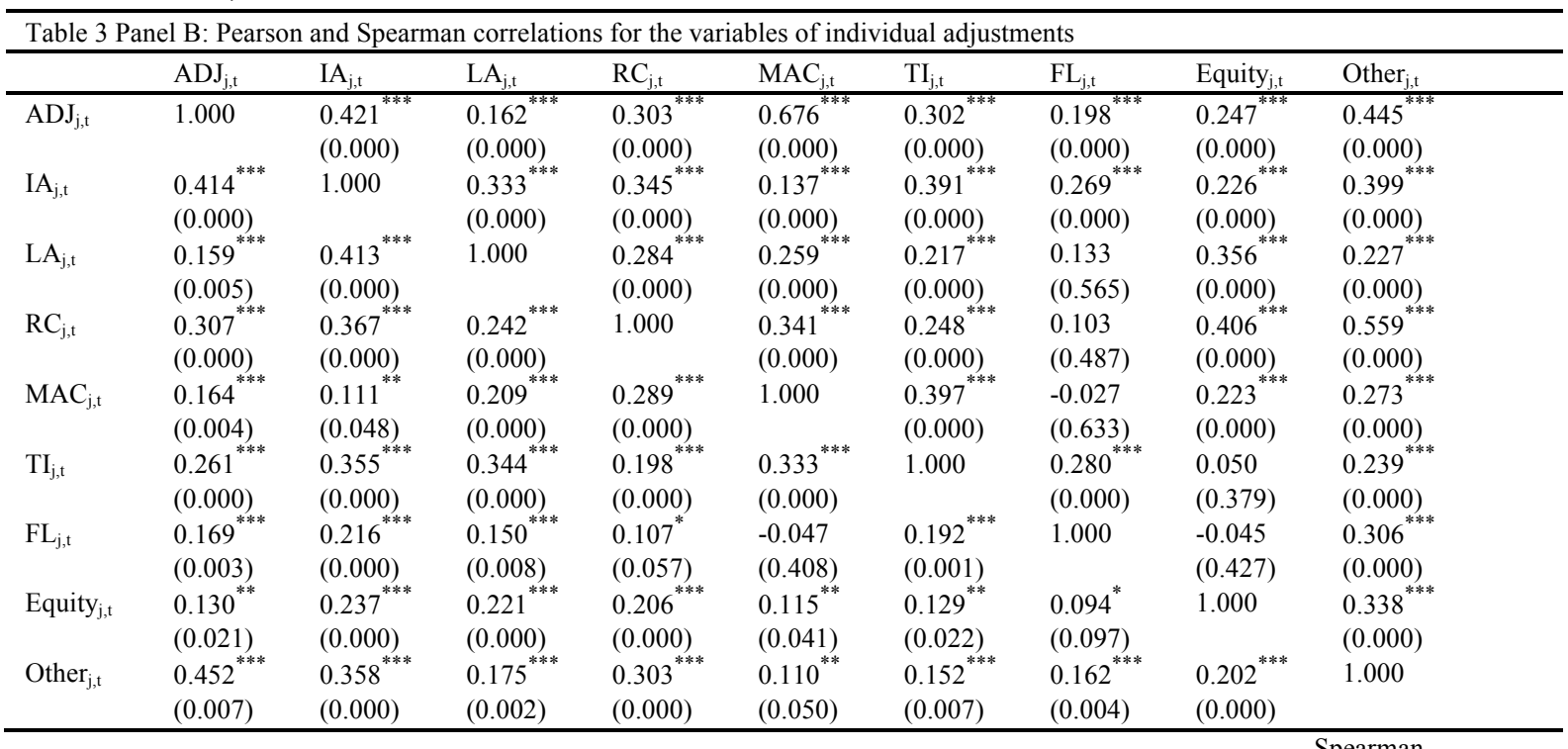

Note: $p$ statistics in parentheses

${ }^{*} \mathrm{p}<0.10,{ }^{* *} \mathrm{p}<0.05,{ }^{* * *} \mathrm{p}<0.01$

Pearson (Spearman) correlations are presented above (below). Variables are defined in Appendix. 
Table 4: Regression results for opportunism reporting (H1)

\begin{tabular}{|c|c|c|c|c|}
\hline \multicolumn{5}{|c|}{$\mathrm{ADJ}_{\mathrm{j}, \mathrm{t}}$ as dependent variable (Equation 1) } \\
\hline & Coef. & Std. Err. & $\mathrm{t}$ & $\mathrm{P}>\mathrm{t}$ \\
\hline $\operatorname{Miss}_{\mathrm{j}, \mathrm{t}}$ & -0.050 & 0.091 & -0.550 & 0.584 \\
\hline $\operatorname{Loss}_{\mathrm{j}, \mathrm{t}}$ & -0.176 & 0.148 & -1.190 & 0.236 \\
\hline $\mathrm{NCPL}_{\mathrm{j}, \mathrm{t}}$ & $0.062^{* *}$ & 0.028 & 2.240 & 0.026 \\
\hline $\operatorname{Miss}_{\mathrm{j}, \mathrm{t}} * \mathrm{NCPL}_{\mathrm{j}, \mathrm{t}}$ & $0.223^{*}$ & 0.124 & 1.800 & 0.072 \\
\hline $\operatorname{Loss}_{\mathrm{j}, \mathrm{t}}{ }^{*} \mathrm{NCPL} \mathrm{L}_{\mathrm{j}, \mathrm{t}}$ & $0.938^{* * *}$ & 0.107 & 8.750 & 0.000 \\
\hline Capital $_{\mathrm{j}, \mathrm{t}}$ & $-0.071^{*}$ & 0.040 & -1.770 & 0.077 \\
\hline $\operatorname{Size}_{\mathrm{j}, \mathrm{t}}$ & -0.011 & 0.019 & -0.550 & 0.581 \\
\hline Leverage $_{\mathrm{j}, \mathrm{t}}$ & 0.072 & 0.104 & 0.690 & 0.487 \\
\hline Sales $_{\mathrm{j}, \mathrm{t}}$ & $0.193^{*}$ & 0.116 & 1.660 & 0.097 \\
\hline MtoB $_{\mathrm{j}, \mathrm{t}}$ & 0.009 & 0.042 & 0.220 & 0.823 \\
\hline $\mathrm{ROE}_{\mathrm{j}, \mathrm{t}}$ & $-0.371^{* * *}$ & 0.102 & -3.650 & 0.000 \\
\hline $\mathrm{SDE}_{\mathrm{j}, \mathrm{t}}$ & 0.064 & 0.121 & 0.530 & 0.596 \\
\hline $\mathrm{NOA}_{\mathrm{j}, \mathrm{t}}$ & -0.051 & 0.043 & -1.170 & 0.242 \\
\hline _cons & 0.315 & 0.245 & 1.290 & 0.199 \\
\hline Time effects & YES & & & \\
\hline Industry effects & YES & & & \\
\hline Number of obs. & 407 & & & \\
\hline Adjusted R-squared & $24.48 \%$ & & & \\
\hline
\end{tabular}


Table 5: Regression results for persistence of adjustments (H2a)

\begin{tabular}{|c|c|c|c|c|c|c|}
\hline & \multicolumn{3}{|c|}{$\mathrm{OE}_{\mathrm{j}, t+1}$ as dependent variable } & \multicolumn{3}{|c|}{$\mathrm{OE}_{\mathrm{j}, \Sigma \mathrm{t}+1 \mathrm{to} 2}$ as dependent variable } \\
\hline & Coef. & Coef. & Coef. & Coef. & Coef. & Coef. \\
\hline & (Equation 2ai) & (Equation 2aii) & (Equation 2aiii) & (Equation 2a iv) & (Equation 2a v) & (Equation 2a vi) \\
\hline \multirow[t]{2}{*}{$\mathrm{UEPS}_{\mathrm{j}, \mathrm{t}}$} & $0.240^{* * *}$ & $0.275^{* * *}$ & $0.282^{* * *}$ & $0.596^{* * *}$ & $0.442^{* *}$ & $0.433^{* *}$ \\
\hline & $(3.330)$ & $(2.620)$ & $(2.670)$ & $(3.660)$ & $(2.280)$ & $(2.340)$ \\
\hline \multirow[t]{2}{*}{$\mathrm{ADJ}_{\mathrm{j}, \mathrm{t}}$} & -0.005 & -0.006 & -0.008 & -0.001 & -0.043 & -0.025 \\
\hline & $(-0.060)$ & $(-0.040)$ & $(-0.030)$ & $(-0.010)$ & $(-0.150)$ & $(-0.090)$ \\
\hline \multirow[t]{2}{*}{$\mathrm{NCPL}_{\mathrm{j}, \mathrm{t}}$} & 0.046 & 0.024 & 0.038 & 0.001 & 0.034 & 0.012 \\
\hline & $(0.450)$ & $(0.230)$ & $(0.380)$ & $(0.010)$ & $(0.180)$ & $(0.060)$ \\
\hline \multirow[t]{2}{*}{$\mathrm{ADJ}_{\mathrm{j}, \mathrm{t}} * \mathrm{NCPL}_{\mathrm{j}, \mathrm{t}}$} & $-0.256^{* * *}$ & $-0.265^{* * *}$ & $-0.255^{* * *}$ & $-0.598^{* * *}$ & $-0.553^{* *}$ & $-0.542^{* *}$ \\
\hline & $(-3.040)$ & $(-3.130)$ & $(-3.070)$ & $(-2.910)$ & $(-2.320)$ & $(-2.280)$ \\
\hline \multirow[t]{2}{*}{ Miss $_{\mathrm{j}, \mathrm{t}}$} & & 0.112 & & & 0.166 & \\
\hline & & $(1.370)$ & & & $(1.110)$ & \\
\hline \multirow{2}{*}{\multicolumn{2}{|c|}{$\mathrm{ADJ}_{\mathrm{j}, \mathrm{t}} * \mathrm{Miss}_{\mathrm{j}, \mathrm{t}} * \mathrm{NCPL}_{\mathrm{j}, \mathrm{t}}$}} & $-0.016^{* * *}$ & & & $-0.060^{* * *}$ & \\
\hline & & $(-3.980)$ & & & $(-3.270)$ & \\
\hline \multirow[t]{2}{*}{$\operatorname{Loss}_{\mathrm{j}, \mathrm{t}}$} & & & $0.078^{*}$ & & & 0.165 \\
\hline & & & $(1.750)$ & & & $(0.920)$ \\
\hline \multirow{2}{*}{\multicolumn{2}{|c|}{$\operatorname{ADJ}_{\mathrm{j}, \mathrm{t}} * \operatorname{Loss}_{\mathrm{j}, \mathrm{t}} * \mathrm{NCPL}_{\mathrm{j}, \mathrm{t}}$}} & & $-0.096^{* *}$ & & & $-0.103^{* * *}$ \\
\hline & & & $(-2.180)$ & & & $(-3.020)$ \\
\hline \multirow[t]{2}{*}{ Capital $_{\mathrm{j}, \mathrm{t}}$} & $0.112^{* *}$ & $0.110^{* *}$ & $0.113^{* *}$ & $0.226^{* * *}$ & $0.223^{* * *}$ & $0.228^{* * *}$ \\
\hline & $(2.490)$ & $(2.430)$ & $(2.520)$ & $(2.730)$ & $(2.680)$ & $(2.750)$ \\
\hline \multirow[t]{2}{*}{ Size $_{j, t}$} & $-0.081^{* * *}$ & $-0.081^{* * *}$ & $-0.083^{* * *}$ & $-0.173^{* * *}$ & $-0.173^{* * *}$ & $-0.177^{* * *}$ \\
\hline & $(-3.270)$ & $(-3.270)$ & $(-3.360)$ & $(-3.800)$ & $(-3.800)$ & $(-3.880)$ \\
\hline \multirow[t]{2}{*}{ Leverage $_{\mathrm{j}, \mathrm{t}}$} & $0.535^{* * *}$ & $0.535^{* * *}$ & $0.535^{* * *}$ & $1.056^{* * *}$ & $1.059^{* * *}$ & $1.055^{* * *}$ \\
\hline & -4.080 & -4.080 & -4.080 & -4.390 & -4.390 & -4.380 \\
\hline \multirow[t]{2}{*}{ Sales $\mathrm{G}_{\mathrm{j}, \mathrm{t}}$} & 0.039 & 0.021 & 0.021 & 0.107 & 0.194 & 0.138 \\
\hline & $(0.280)$ & $(0.140)$ & $(0.150)$ & $(0.420)$ & $(0.720)$ & $(0.540)$ \\
\hline \multirow[t]{2}{*}{ MtoB $_{\mathrm{j}, \mathrm{t}}$} & -0.007 & -0.007 & -0.006 & -0.032 & $-0.032^{*}$ & -0.031 \\
\hline & $(-0.640)$ & $(-0.690)$ & $(-0.590)$ & $(-1.630)$ & $(-1.670)$ & $(-1.580)$ \\
\hline \multirow[t]{2}{*}{$\mathrm{ROE}_{\mathrm{j}, \mathrm{t}}$} & $0.547^{* * *}$ & $0.527^{* * *}$ & $0.516^{* * *}$ & $1.161^{* * *}$ & $1.132^{* * *}$ & $1.108^{* * *}$ \\
\hline & $(4.380)$ & $(4.180)$ & $(4.000)$ & $(5.060)$ & $(4.880)$ & $(4.670)$ \\
\hline \multirow[t]{2}{*}{$\mathrm{SDE}_{\mathrm{j}, \mathrm{t}}$} & $-1.631^{* * *}$ & $-1.620^{* * *}$ & $-1.617^{* * *}$ & $-2.236^{* * *}$ & $-2.220^{* * *}$ & $-2.211^{* * *}$ \\
\hline & $(-10.830)$ & $(-10.750)$ & $(-10.670)$ & $(-8.090)$ & $(-8.010)$ & $(-7.950)$ \\
\hline \multirow[t]{2}{*}{$\mathrm{NOA}_{\mathrm{j}, \mathrm{t}}$} & 0.046 & 0.045 & 0.046 & 0.111 & 0.110 & 0.111 \\
\hline & $(0.840)$ & $(0.830)$ & $(0.840)$ & $(1.120)$ & (1.110) & $(1.120)$ \\
\hline \multirow[t]{2}{*}{ _cons } & 0.133 & 0.208 & 0.171 & 0.373 & 0.484 & 0.439 \\
\hline & $(0.510)$ & $(0.780)$ & $(0.650)$ & $(0.780)$ & $(0.990)$ & $(0.910)$ \\
\hline Time effects & YES & YES & YES & YES & YES & YES \\
\hline Industry & YES & YES & YES & YES & YES & YES \\
\hline Number of obs. & 407 & 407 & 407 & 407 & 407 & 407 \\
\hline $\begin{array}{l}\text { Adjusted R- } \\
\text { squared }\end{array}$ & $21.75 \%$ & $21.77 \%$ & $21.63 \%$ & $16.04 \%$ & $15.98 \%$ & $15.88 \%$ \\
\hline
\end{tabular}


and 1.53 .

Table 6: Regression results for persistence of individual adjustments (H2b)

\begin{tabular}{|c|c|c|c|c|}
\hline & \multicolumn{2}{|c|}{ Non-compliance firms } & \multicolumn{2}{|c|}{ Compliance firms } \\
\hline & $\begin{array}{l}\mathrm{OE}_{\mathrm{j}, \mathrm{t}+1} \text { as dependent } \\
\text { variable }\end{array}$ & $\begin{array}{l}\mathrm{OE}_{\mathrm{j}, \Sigma \mathrm{t}+1 \text { to2 }} \text { as dependent } \\
\text { variable }\end{array}$ & $\begin{array}{l}\mathrm{OE}_{\mathrm{j}, t+1} \text { as dependent } \\
\text { variable }\end{array}$ & $\begin{array}{l}\mathrm{OE}_{\mathrm{j}, \Sigma \mathrm{t}+1 \mathrm{to} 2} \text { as dependent } \\
\text { variable }\end{array}$ \\
\hline & Coef. & Coef. & Coef. & Coef. \\
\hline & (Equation 2bi) & (Equation 2bii) & (Equation 2bi) & (Equation 2bii) \\
\hline \multirow[t]{2}{*}{$\mathrm{UEPS}_{\mathrm{j}, \mathrm{t}}$} & $0.263^{* * *}$ & $0.272^{* * *}$ & $0.249^{* * *}$ & $0.300^{* * *}$ \\
\hline & $(5.510)$ & $(7.270)$ & $(8.150)$ & $(9.010)$ \\
\hline \multirow[t]{2}{*}{$\mathrm{IA}_{\mathrm{j}, \mathrm{t}}$} & -0.012 & -0.010 & 0.008 & 0.008 \\
\hline & $(-0.580)$ & $(-0.620)$ & $(0.600)$ & $(0.580)$ \\
\hline \multirow[t]{2}{*}{$\mathrm{LA}_{\mathrm{j}, \mathrm{t}}$} & -0.016 & 0.001 & -0.010 & -0.007 \\
\hline & $(-0.670)$ & $(0.080)$ & $(-0.680)$ & $(-0.510)$ \\
\hline \multirow{2}{*}{$\mathrm{MAC}_{\mathrm{j}, \mathrm{t}}$} & -0.026 & -0.016 & 0.003 & 0.006 \\
\hline & $(-1.020)$ & $(-0.800)$ & $(0.180)$ & $(0.370)$ \\
\hline \multirow[t]{2}{*}{$\mathrm{RC}_{\mathrm{j}, \mathrm{t}}$} & -0.007 & -0.006 & -0.017 & -0.015 \\
\hline & $(-0.320)$ & $(-0.350)$ & $(-1.240)$ & $(-1.090)$ \\
\hline \multirow[t]{2}{*}{$\mathrm{TI}_{\mathrm{j}, \mathrm{t}}$} & -0.006 & 0.006 & -0.010 & -0.007 \\
\hline & $(-0.280)$ & $(0.340)$ & $(-0.310)$ & $(-0.500)$ \\
\hline \multirow[t]{2}{*}{$\mathrm{FL}_{\mathrm{j}, \mathrm{t}}$} & 0.019 & $-0.005^{*}$ & 0.024 & 0.016 \\
\hline & $(0.920)$ & $(-1.810)$ & $(1.380)$ & $(0.930)$ \\
\hline \multirow[t]{2}{*}{ Equity $_{\mathrm{j}, \mathrm{t}}$} & $-0.017^{* *}$ & $-0.061^{* *}$ & -0.018 & -0.014 \\
\hline & $(-2.040)$ & $(-2.220)$ & $(-0.910)$ & $(-0.730)$ \\
\hline \multirow[t]{2}{*}{ Other $_{\mathrm{j}, \mathrm{t}}$} & $-0.034^{* * *}$ & $-0.168^{* * *}$ & $-0.029^{*}$ & $-0.026^{*}$ \\
\hline & $(-3.210)$ & $(-3.830)$ & $(-1.810)$ & $(-1.660)$ \\
\hline \multirow[t]{2}{*}{$\mathrm{MtoB}_{\mathrm{j}, \mathrm{t}}$} & $0.074^{* *}$ & 0.012 & $0.057^{* *}$ & $0.049^{*}$ \\
\hline & $(2.460)$ & $(0.630)$ & $(2.080)$ & $(1.800)$ \\
\hline \multirow[t]{2}{*}{ Size $_{\mathrm{j}, \mathrm{t}}$} & $-0.036^{* * *}$ & $-0.027^{* * *}$ & $-0.022^{* * *}$ & $-0.021^{* * *}$ \\
\hline & $(-5.390)$ & $(-5.240)$ & $(-5.150)$ & $(-4.930)$ \\
\hline \multirow[t]{2}{*}{ Leverage $_{j, t}$} & $0.259^{* * *}$ & $0.239^{* * *}$ & $0.166^{* * *}$ & $0.160^{* * *}$ \\
\hline & $(8.700)$ & $(10.260)$ & $(8.730)$ & $(8.580)$ \\
\hline \multirow[t]{2}{*}{$\mathrm{ROE}_{\mathrm{j}, \mathrm{t}}$} & 0.117 & $0.049^{* * *}$ & $0.038^{* * *}$ & $0.036^{* * *}$ \\
\hline & $(1.370)$ & $(4.100)$ & $(3.850)$ & $(3.730)$ \\
\hline \multirow[t]{2}{*}{ Sales $_{\mathrm{j}, \mathrm{t}}$} & $0.033^{* *}$ & $0.038^{* *}$ & $0.021^{* *}$ & $0.022^{* *}$ \\
\hline & $(2.230)$ & $(2.010)$ & $(2.400)$ & $(2.580)$ \\
\hline \multirow[t]{2}{*}{ Capital $_{\mathrm{j}, \mathrm{t}}$} & -0.005 & -0.003 & -0.012 & $0.102^{* * *}$ \\
\hline & $(-0.240)$ & $(-0.220)$ & $(-0.600)$ & $(3.520)$ \\
\hline \multirow[t]{2}{*}{$\mathrm{NOA}_{\mathrm{j}, \mathrm{t}}$} & $-0.027^{* *}$ & -0.034 & -0.001 & -0.003 \\
\hline & $(-2.300)$ & $(-1.440)$ & $(-0.220)$ & $(-0.180)$ \\
\hline \multirow[t]{2}{*}{$\mathrm{SDE}_{\mathrm{j}, \mathrm{t}}$} & $-0.209^{* * *}$ & -0.255 & $-0.203^{* * *}$ & -0.177 \\
\hline & $(-2.780)$ & $(-3.350)$ & $(-2.780)$ & $(-1.150)$ \\
\hline \multirow[t]{2}{*}{ _cons } & $0.386^{* * *}$ & $0.276^{* * *}$ & $0.207^{* * *}$ & $0.179^{* * *}$ \\
\hline & $(6.430)$ & $(5.970)$ & $(5.630)$ & $(4.840)$ \\
\hline Time effects & YES & YES & YES & YES \\
\hline
\end{tabular}




\begin{tabular}{|c|c|c|c|c|}
\hline $\begin{array}{l}\text { Industry } \\
\text { effects }\end{array}$ & YES & YES & YES & YES \\
\hline $\begin{array}{l}\text { Number of } \\
\text { obs. }\end{array}$ & 223 & 223 & 184 & 184 \\
\hline $\begin{array}{l}\text { Adjusted R- } \\
\text { squared }\end{array}$ & $44.71 \%$ & $54.62 \%$ & $53.79 \%$ & $55.71 \%$ \\
\hline
\end{tabular}
1.85 respectively.

Table 7: Regression results for value relevance (H3)

\begin{tabular}{|c|c|c|c|}
\hline & \multirow{2}{*}{$\begin{array}{l}\text { Stock }_{\mathrm{j}, \mathrm{t}} \text { as } \\
\text { dependent variable }\end{array}$} & \multicolumn{2}{|c|}{$\begin{array}{l}\text { Stock }_{\mathrm{j}, \mathrm{t}} \text { as dependent variable } \\
\text { with income-increasing } \\
\text { exclusions only }\end{array}$} \\
\hline & & Coef. & Coef. \\
\hline & (Equation 3a) & (Equation 3b) & (Equation 3c) \\
\hline \multirow[t]{2}{*}{$\mathrm{UEPS}_{\mathrm{j}, \mathrm{t}}$} & $0.615^{* * *}$ & $0.643^{* * *}$ & $0.631^{* * *}$ \\
\hline & $(6.230)$ & $(6.920)$ & $(7.350)$ \\
\hline \multirow[t]{2}{*}{$\operatorname{NCPL}_{j, t}$} & $0.470^{* * *}$ & $0.500^{* * *}$ & $0.402^{* * *}$ \\
\hline & $(2.920)$ & $(3.270)$ & $(2.790)$ \\
\hline \multirow[t]{2}{*}{$\mathrm{UEPS}_{\mathrm{j}, \mathrm{t}} * \mathrm{NCPL}_{\mathrm{j}, \mathrm{t}}$} & $-0.179^{* * *}$ & -0.175 & $-0.189^{*}$ \\
\hline & $(-4.840)$ & $(-1.510)$ & $(-1.720)$ \\
\hline \multirow{2}{*}{\multicolumn{2}{|c|}{ Miss $_{\mathrm{i}, \mathrm{t}}$}} & $-0.394^{* * *}$ & \\
\hline & & $(-3.370)$ & \\
\hline \multirow{2}{*}{\multicolumn{2}{|c|}{$\mathrm{UEPS}_{\mathrm{j}, \mathrm{t}} * \operatorname{Miss}_{\mathrm{j}, \mathrm{t}} * \mathrm{NCPL}_{\mathrm{j}, \mathrm{t}}$}} & $0.122^{* * *}$ & \\
\hline & & $(2.940)$ & \\
\hline \multirow[t]{2}{*}{$\operatorname{Loss}_{i, t}$} & & & $-0.511^{* * *}$ \\
\hline & & & $(-6.470)$ \\
\hline \multirow{2}{*}{\multicolumn{2}{|c|}{$\operatorname{UEPS}_{\mathrm{j}, \mathrm{t}} * \operatorname{Loss}_{\mathrm{j}, \mathrm{t}} * \mathrm{NCPL}_{\mathrm{j}, \mathrm{t}}$}} & & $0.341^{* * *}$ \\
\hline & & & $(3.990)$ \\
\hline \multirow[t]{2}{*}{ BVEPS $_{\mathrm{j}, \mathrm{t}}$} & $0.136^{* *}$ & $0.106^{*}$ & $0.095^{*}$ \\
\hline & $(2.610)$ & $(1.910)$ & $(1.800)$ \\
\hline \multirow[t]{2}{*}{ _cons } & $-2.849^{* * *}$ & $-2.656^{* * *}$ & $-2.637^{* * *}$ \\
\hline & $(-16.390)$ & $(-14.820)$ & $(-16.470)$ \\
\hline Time effects & YES & YES & YES \\
\hline Industry effects & YES & YES & YES \\
\hline Number of obs. & 407 & 321 & 321 \\
\hline $\begin{array}{l}\text { Adjusted R- } \\
\text { squared }\end{array}$ & $45.01 \%$ & $57.44 \%$ & $58.27 \%$ \\
\hline
\end{tabular}


Table 8: Regression results for additional test (the impact of income-decreasing exclusions on future operating earnings)

\begin{tabular}{|c|c|c|c|c|c|c|c|c|}
\hline & \multicolumn{4}{|c|}{ H2ai with $\mathrm{OE}_{\mathrm{j}, t+1}$ as dependent variable } & \multicolumn{4}{|c|}{ H2aii with $\mathrm{OE}_{\mathrm{j}, \Sigma \mathrm{t}+1 \mathrm{to} 2}$ as dependent variable } \\
\hline & Coef. & Std. Err. & $\mathrm{t}$ & $\mathrm{P}>\mathrm{t}$ & Coef. & Std. Err. & $\mathrm{t}$ & $\mathrm{P}>\mathrm{t}$ \\
\hline UEPS $_{\mathrm{j}, \mathrm{t}}$ & $0.235^{* * *}$ & 0.083 & 2.880 & 0.004 & $0.587^{* * *}$ & 0.163 & 3.180 & 0.000 \\
\hline $\operatorname{DeADJ}_{\mathrm{j}, \mathrm{t}}$ & 0.002 & 0.071 & 0.030 & 0.977 & 0.027 & 0.131 & 0.200 & 0.838 \\
\hline $\mathrm{NCPL}_{\mathrm{j}, \mathrm{t}}$ & 0.045 & 0.101 & 0.440 & 0.632 & 0.001 & 0.185 & 0.010 & 0.965 \\
\hline $\begin{array}{l}\operatorname{DeADJ}_{\mathrm{j}, \mathrm{t}} * \mathrm{NCP} \\
\mathrm{L}_{\mathrm{j}, \mathrm{t}}\end{array}$ & 0.048 & 0.107 & 0.450 & 0.653 & 0.062 & 0.197 & 0.320 & 0.753 \\
\hline Capital $_{\mathrm{j}, \mathrm{t}}$ & $0.111^{* *}$ & 0.045 & 2.460 & 0.014 & $0.226^{* * *}$ & 0.083 & 2.720 & 0.007 \\
\hline Size $_{\mathrm{j}, \mathrm{t}}$ & $-0.081^{* * *}$ & 0.025 & -3.280 & 0.001 & $-0.173^{* * *}$ & 0.045 & -3.800 & 0.000 \\
\hline Leverage $_{j, t}$ & $0.523^{* * *}$ & 0.131 & 4.000 & 0.000 & $1.036^{* * *}$ & 0.240 & 4.320 & 0.000 \\
\hline SalesG $_{\mathrm{j}, \mathrm{t}}$ & 0.028 & 0.140 & 0.200 & 0.842 & -0.134 & 0.257 & -0.520 & 0.602 \\
\hline MtoB $_{j, t}$ & -0.007 & 0.011 & -0.650 & 0.513 & -0.032 & 0.019 & -1.640 & 0.102 \\
\hline $\mathrm{ROE}_{\mathrm{j}, \mathrm{t}}$ & $0.550^{* * *}$ & 0.125 & 4.390 & 0.000 & $1.168^{* * *}$ & 0.230 & 5.080 & 0.000 \\
\hline $\mathrm{SDE}_{\mathrm{j}, \mathrm{t}}$ & $-1.625^{* * *}$ & 0.151 & -10.790 & 0.000 & $-2.223^{* * *}$ & 0.277 & -8.040 & 0.000 \\
\hline $\mathrm{NOA}_{\mathrm{j}, \mathrm{t}}$ & 0.048 & 0.054 & 0.890 & 0.371 & 0.117 & 0.099 & 1.180 & 0.240 \\
\hline _cons & 0.148 & 0.260 & 0.570 & 0.569 & 0.396 & 0.478 & 0.830 & 0.408 \\
\hline Time effects & YES & & & & YES & & & \\
\hline Industry & YES & & & & YES & & & \\
\hline $\begin{array}{l}\text { Number of } \\
\text { obs. }\end{array}$ & 407 & & & & 407 & & & \\
\hline $\begin{array}{l}\text { Adjusted R- } \\
\text { squared }\end{array}$ & $21.67 \%$ & & & & $15.99 \%$ & & & \\
\hline
\end{tabular}


Table 9: Regression results for additional test (the impact of other earnings benchmark)

\begin{tabular}{|c|c|c|c|c|}
\hline & Coef. & Std. Err. & $\mathrm{t}$ & $\mathrm{P}>\mathrm{t}$ \\
\hline Profit $_{\mathrm{j}, \mathrm{t}}$ & -0.137 & 0.096 & -1.420 & 0.155 \\
\hline $\operatorname{Loss}_{\mathrm{j}, \mathrm{t}}$ & -0.083 & 0.139 & -0.590 & 0.553 \\
\hline $\operatorname{NCPL}_{j, t}$ & $0.062^{* *}$ & 0.030 & 2.090 & 0.042 \\
\hline Profit $_{\mathrm{j}, \mathrm{t}} * \mathrm{NCPL}_{\mathrm{j}, \mathrm{t}}$ & $0.363^{* * *}$ & 0.084 & 3.040 & 0.002 \\
\hline $\operatorname{Loss}_{\mathrm{j}, \mathrm{t}} * \mathrm{NCPL}_{\mathrm{j}, \mathrm{t}}$ & $0.963^{* * *}$ & 0.102 & 9.420 & 0.000 \\
\hline Capital $_{\mathrm{j}, \mathrm{t}}$ & $-0.073^{*}$ & 0.040 & -1.830 & 0.068 \\
\hline Size $_{j, t}$ & -0.002 & 0.020 & -0.090 & 0.925 \\
\hline Leverage $_{j, t}$ & 0.074 & 0.105 & 0.710 & 0.479 \\
\hline Sales $_{\mathrm{j}, \mathrm{t}}$ & 0.146 & 0.112 & 1.300 & 0.193 \\
\hline MtoB $_{\mathrm{j}, \mathrm{t}}$ & 0.004 & 0.041 & 0.090 & 0.928 \\
\hline $\mathrm{ROE}_{\mathrm{j}, \mathrm{t}}$ & $-0.385^{* * *}$ & 0.102 & -3.780 & 0.000 \\
\hline $\mathrm{SDE}_{\mathrm{j}, \mathrm{t}}$ & 0.053 & 0.121 & 0.430 & 0.664 \\
\hline $\mathrm{NOA}_{\mathrm{j}, \mathrm{t}}$ & -0.056 & 0.043 & -1.300 & 0.195 \\
\hline _cons & 0.294 & 0.242 & 1.220 & 0.224 \\
\hline Time effects & YES & & & \\
\hline Industry effects & YES & & & \\
\hline Number of obs. & 407 & & & \\
\hline Adjusted R-squared & $24.19 \%$ & & & \\
\hline
\end{tabular}

Table 9 Panel B: re-test H2a by replacing Miss $\mathrm{j}_{\mathrm{j}, \mathrm{t}}$ with Profit $\mathrm{j}_{\mathrm{j}, \mathrm{t}}$

\begin{tabular}{|c|c|c|c|c|c|c|c|c|}
\hline & \multicolumn{4}{|c|}{$\mathrm{OE}_{\mathrm{j}, \mathrm{t}+1}$ as dependent variable } & \multicolumn{4}{|c|}{$\mathrm{OE}_{\mathrm{j}, \Sigma \mathrm{t}+1 \mathrm{to2}}$ as dependent variable } \\
\hline & Coef. & Std. Err. & $\mathrm{t}$ & $\mathrm{P}>\mathrm{t}$ & Coef. & Std. Err. & $\mathrm{t}$ & $\mathrm{P}>\mathrm{t}$ \\
\hline UEPS $_{\mathrm{j}, \mathrm{t}}$ & $0.232^{* * *}$ & 0.106 & 3.680 & 0.000 & $0.469^{* *}$ & 0.194 & 2.420 & 0.016 \\
\hline $\mathrm{ADJ}_{\mathrm{j}, \mathrm{t}}$ & 0.027 & 0.158 & 0.170 & 0.865 & 0.004 & 0.290 & 0.010 & 0.989 \\
\hline $\mathrm{NCPL}_{\mathrm{j}, \mathrm{t}}$ & 0.05 & 0.101 & 0.490 & 0.623 & 0.007 & 0.187 & 0.040 & 0.971 \\
\hline $\mathrm{ADJ}_{\mathrm{j}, \mathrm{t}} * \mathrm{NCPL}_{\mathrm{j}, \mathrm{t}}$ & $-0.260^{* * *}$ & 0.085 & -4.200 & 0.000 & $-0.561^{* *}$ & 0.195 & -2.360 & 0.018 \\
\hline Profit $_{j, t}$ & -0.122 & 0.091 & -1.340 & 0.179 & -0.181 & 0.168 & -1.080 & 0.281 \\
\hline $\operatorname{ADJ}_{\mathrm{j}, \mathrm{t}} *$ Profit $_{\mathrm{j}, \mathrm{t}} * \mathrm{NCPL}_{\mathrm{j}, \mathrm{t}}$ & $-0.022^{* * *}$ & 0.073 & -2.950 & 0.004 & $-0.093^{* * *}$ & 0.054 & -3.010 & 0.003 \\
\hline Capital $_{\mathrm{j}, \mathrm{t}}$ & $0.115^{* *}$ & 0.045 & 2.550 & 0.011 & $0.231^{* * *}$ & 0.083 & 2.780 & 0.006 \\
\hline Size $_{j, t}$ & $-0.071^{* * *}$ & 0.026 & -2.780 & 0.006 & $-0.158^{* * *}$ & 0.047 & -3.350 & 0.001 \\
\hline Leverage $_{\mathrm{j}, \mathrm{t}}$ & $0.553^{* * *}$ & 0.132 & 4.200 & 0.000 & $1.084^{* * *}$ & 0.242 & 4.480 & 0.000 \\
\hline Sales $\mathrm{G}_{\mathrm{j}, \mathrm{t}}$ & 0.029 & 0.139 & 0.210 & 0.835 & -0.123 & 0.255 & -0.480 & 0.630 \\
\hline $\mathrm{MtoB}_{\mathrm{j}, \mathrm{t}}$ & -0.008 & 0.011 & -0.720 & 0.472 & $-0.033^{*}$ & 0.019 & -1.680 & 0.093 \\
\hline $\mathrm{ROE}_{\mathrm{j}, \mathrm{t}}$ & $0.545^{* * *}$ & 0.125 & 4.360 & 0.000 & $1.158^{* * *}$ & 0.230 & 5.040 & 0.000 \\
\hline $\mathrm{SDE}_{\mathrm{j}, \mathrm{t}}$ & $-1.645^{* * *}$ & 0.151 & -10.900 & 0.000 & $-2.257^{* * *}$ & 0.277 & -8.140 & 0.000 \\
\hline $\mathrm{NOA}_{j, t}$ & 0.041 & 0.054 & 0.750 & 0.452 & 0.104 & 0.100 & 1.050 & 0.296 \\
\hline _cons & 0.083 & 0.263 & 0.320 & 0.752 & 0.293 & 0.485 & 0.600 & 0.546 \\
\hline Time effects & YES & & & & YES & & & \\
\hline Industry & YES & & & & YES & & & \\
\hline
\end{tabular}




\begin{tabular}{|c|c|c|c|c|}
\hline Number of obs. & 407 & & & \\
\hline Adjusted R-squared & $21.75 \%$ & & & \\
\hline Table 9 Panel C: re-test $\mathrm{H}$ & by replacing & iss $_{\mathrm{i}, \mathrm{t}}$ with & $\overline{\mathrm{Cit}_{\mathrm{i}, \mathrm{t}}}$ & \\
\hline & Coef. & Std. Err. & $\mathrm{t}$ & $\mathrm{P}>\mathrm{t}$ \\
\hline UEPS $_{\mathrm{i}, \mathrm{t}}$ & $0.615^{* * *}$ & 0.099 & 6.230 & 0.000 \\
\hline $\operatorname{NCPL}_{\mathrm{i}, \mathrm{t}}$ & $0.454^{* * *}$ & 0.161 & 2.810 & 0.005 \\
\hline $\mathrm{UEPS}_{\mathrm{j}, \mathrm{t}} * \mathrm{NCPL}_{\mathrm{i}, \mathrm{t}}$ & -0.050 & 0.079 & -0.410 & 0.685 \\
\hline Profiti, & $0.228^{* * *}$ & 0.154 & 3.260 & 0.001 \\
\hline UEPS $_{\mathrm{j}, \mathrm{t}} *$ Profit $_{\mathrm{j}, \mathrm{t}} * \mathrm{NCPL}_{\mathrm{j}, \mathrm{t}}$ & $0.106^{* *}$ & 0.085 & 2.500 & 0.013 \\
\hline BVEPS $_{\mathrm{i}, \mathrm{t}}$ & $0.135^{* *}$ & 0.052 & 2.590 & 0.010 \\
\hline cons & $-2.849^{* * *}$ & 0.174 & -16.390 & 0.000 \\
\hline Time effects & YES & & & \\
\hline Industry effects & YES & & & \\
\hline Number of obs. & 321 & & & \\
\hline Adjusted R-squared & $52.68 \%$ & & & \\
\hline
\end{tabular}

407

$15.95 \%$

Note: ${ }^{*} \mathrm{p}<0.10,{ }^{* *} \mathrm{p}<0.05,{ }^{* * *} \mathrm{p}<0.01$. Variables are defined in Appendix. The mean of VIF is between 1.72, 2.09, and 2.42 respectively. 


\section{Appendix}

\begin{tabular}{|c|c|}
\hline Variables & Descriptions \\
\hline $\operatorname{Miss}_{\mathrm{j}, \mathrm{t}}$ & $\begin{array}{l}\text { A dummy variable that equals } 1 \text { if firm j's earnings before tax in year } t \text { is less } \\
\text { than earnings before tax in year } t-1 \text {, and zero otherwise }\end{array}$ \\
\hline $\operatorname{Loss}_{\mathrm{j}, \mathrm{t}}$ & $\begin{array}{l}\text { A dummy variable that equals } 1 \text { if firm } \mathrm{j} \text { made IFRS losses in year } \mathrm{t} \text {, or zero } \\
\text { otherwise }\end{array}$ \\
\hline $\mathrm{UEPS}_{\mathrm{j}, \mathrm{t}}$ & $\begin{array}{l}\text { Actual non-IFRS earnings figures that firms report divided by the number of } \\
\text { shares outstanding for firm } j \text {, in year } t\end{array}$ \\
\hline Stock $_{\mathrm{j}, \mathrm{t}}$ & Stock price for firm $\mathrm{j}$, in year $\mathrm{t}$, on the date of the earnings announcement \\
\hline Profit $_{j, t}$ & $\begin{array}{l}\text { Dummy variable that equals } 1 \text { if firm } j \text { 's achieves a profit with the non-IFRS } \\
\text { earnings, when the IFRS earnings is negative in year } t \text {, and zero otherwise }\end{array}$ \\
\hline $\mathrm{NCPL}_{\mathrm{j}, \mathrm{t}}$ & $\begin{array}{l}\text { A dummy variable, coded as ' } 1 \text { ' if firm } \mathrm{j} \text { does not comply with ASIC } \\
\text { guidelines in year } t \text {, or ' } 0 \text { ' otherwise }\end{array}$ \\
\hline $\mathrm{ADJ}_{\mathrm{j}, \mathrm{t}}$ & $\begin{array}{l}\text { Total actual income-increasing non-IFRS earnings adjustments divided by the } \\
\text { number of shares outstanding for firm } \mathrm{j} \text {, in year } \mathrm{t} \text {. It is calculated as the actual } \\
\text { non-IFRS earnings figures minus the IFRS earnings figures divided by the } \\
\text { number of shares outstanding for firm } \mathrm{j} \text {, in year } \mathrm{t} \text {. We keep positive } \mathrm{ADJ}_{\mathrm{j}, \mathrm{t}} \text { and } \\
\text { set negative } \mathrm{ADJ}_{\mathrm{j}, \mathrm{t}} \text { as } 0 \text {. }\end{array}$ \\
\hline $\operatorname{DeADJ}_{\mathrm{j}, \mathrm{t}}$ & $\begin{array}{l}\text { Total actual income-decreasing non-IFRS earnings adjustments divided by the } \\
\text { number of shares outstanding for firm } \mathrm{j} \text {, in year } \mathrm{t} \text {. It is calculated as actual non- } \\
\text { IFRS earnings figures minus the IFRS earnings figures divided by the number } \\
\text { of shares outstanding for firm } \mathrm{j} \text {, in year } \mathrm{t} \text {. We keep negative figures and set } \\
\text { positive figures as ' } 0 \text { ' }\end{array}$ \\
\hline Miss $_{\mathrm{j}, \mathrm{t}} * \mathrm{NCPL}_{\mathrm{j}, \mathrm{t}}$ & A interaction term between Miss $_{\mathrm{j}, \mathrm{t}}$ and $\mathrm{NCPL}_{\mathrm{j}, \mathrm{t}}$ \\
\hline $\operatorname{Loss}_{\mathrm{j}, \mathrm{t}} * \mathrm{NCPL} \mathrm{j}_{\mathrm{j}, \mathrm{t}}$ & A interaction term between $\operatorname{Loss}_{\mathrm{j}, \mathrm{t}}$ and $\mathrm{NCPL}_{\mathrm{j}, \mathrm{t}}$ \\
\hline $\mathrm{UEPS}_{\mathrm{j}, \mathrm{t}} * \mathrm{NCPL} \mathrm{L}_{\mathrm{j}, \mathrm{t}}$ & A interaction term between $\mathrm{UEPS}_{\mathrm{j}, \mathrm{t}}$ and $\mathrm{NCPL}_{\mathrm{j}, \mathrm{t}}$ \\
\hline $\operatorname{DeADJ}_{\mathrm{j}, \mathrm{t}} * \mathrm{NCPL}_{\mathrm{j}, \mathrm{t}}$ & A interaction term between $\operatorname{DeADJ}_{\mathrm{j}, \mathrm{t}}$ and $\mathrm{NCPL}_{\mathrm{j}, \mathrm{t}}$ \\
\hline $\operatorname{ADJ}_{\mathrm{j}, \mathrm{t}} * \operatorname{Miss}_{\mathrm{j}, \mathrm{t}} * \mathrm{NCPL}_{\mathrm{j}, \mathrm{t}}$ & A interaction term between $\mathrm{ADJ}_{\mathrm{j}, \mathrm{t}} \mathrm{Miss}_{\mathrm{j}, \mathrm{t}}$, and $\mathrm{NCPL}_{\mathrm{j}, \mathrm{t}}$ \\
\hline $\operatorname{ADJ}_{\mathrm{j}, \mathrm{t}} * \operatorname{Loss}_{\mathrm{j}, \mathrm{t}} * \mathrm{NCPL}_{\mathrm{j}, \mathrm{t}}$ & A interaction term between $\mathrm{ADJ}_{\mathrm{j}, \mathrm{t}} \operatorname{Loss}_{\mathrm{j}, \mathrm{t}}$, and $\mathrm{NCPL}_{\mathrm{j}, \mathrm{t}}$ \\
\hline $\mathrm{UEPS}_{\mathrm{j}, \mathrm{t}} * \mathrm{Miss}_{\mathrm{j}, \mathrm{t}} * \mathrm{NCPL}_{\mathrm{j}, \mathrm{t}}$ & A interaction term between $\mathrm{UEPS}_{\mathrm{j}, \mathrm{t}}$ Miss $_{\mathrm{j}, \mathrm{t}}$ and $\mathrm{NCPL}_{\mathrm{j}, \mathrm{t}}$ \\
\hline $\mathrm{UEPS}_{\mathrm{j}, \mathrm{t}} * \operatorname{Loss}_{\mathrm{j}, \mathrm{t}} * \mathrm{NCPL}_{\mathrm{j}, \mathrm{t}}$ & A interaction term between $\operatorname{UEPS}_{\mathrm{j}, \mathrm{t}} \operatorname{Loss}_{\mathrm{j}, \mathrm{t}}$, and NCPL $\mathrm{N}_{\mathrm{j}, \mathrm{t}}$ \\
\hline $\mathrm{UEPS}_{\mathrm{j}, \mathrm{t}} *$ Profit $_{\mathrm{j}, \mathrm{t}} * \mathrm{NCPL}_{\mathrm{j}, \mathrm{t}}$ & A interaction term between $\mathrm{UEPS}_{\mathrm{j}, \mathrm{t}}$ Profit $_{\mathrm{j}, \mathrm{t}}$, and $\mathrm{NCPL}_{\mathrm{j}, \mathrm{t}}$ \\
\hline $\mathrm{IA}_{\mathrm{j}, \mathrm{t}}$ & $\begin{array}{l}\text { Actual impairment of assets figures divided by the number of shares } \\
\text { outstanding for firm } \mathrm{j} \text {, in year } \mathrm{t} \text {, for those firms that do not exclude impairment } \\
\text { of assets, coded as } 0 \text {. }\end{array}$ \\
\hline $\mathrm{LA}_{\mathrm{j}, \mathrm{t}}$ & $\begin{array}{l}\text { Actual losses on asset dispositions or investment figures divided by the } \\
\text { number of shares outstanding for firm } \mathrm{j} \text {, in year } \mathrm{t} \text {, for those firms that do not } \\
\text { exclude losses on asset dispositions or investments, coded as } 0\end{array}$ \\
\hline $\mathrm{RC}_{\mathrm{j}, \mathrm{t}}$ & $\begin{array}{l}\text { Actual redundancies and/or restructuring costs divided by the number of shares } \\
\text { outstanding for firm } \mathrm{j} \text {, in year } \mathrm{t} \text {, for those firms that do not exclude } \\
\text { redundancies or restructuring costs, coded as } 0 \text {. }\end{array}$ \\
\hline $\mathrm{MAC}_{\mathrm{j}, \mathrm{t}}$ & $\begin{array}{l}\text { Actual asset merge or demerge and acquisition-transaction costs divided by the } \\
\text { number of shares outstanding for firm } \mathrm{j} \text {, in year } \mathrm{t} \text {, for those that firms do not } \\
\text { exclude asset merge or demerge and acquisition-transaction costs, coded as } 0 \text {. }\end{array}$ \\
\hline $\mathrm{TI}_{\mathrm{j}, \mathrm{t}}$ & $\begin{array}{l}\text { Actual figures of expenses related to tax or interest effects divided by the } \\
\text { number of shares outstanding for firm } \mathrm{j} \text {, in year } t \text {, for those firms that do not } \\
\text { exclude expenses related to tax or interest effects, coded as } 0 \text {. }\end{array}$ \\
\hline $\mathrm{FL}_{\mathrm{j}, \mathrm{t}}$ & $\begin{array}{l}\text { Actual losses on foreign exchange divided by the number of shares outstanding } \\
\text { for firm } j \text {, in year } t \text {, for those firms that do not exclude losses on foreign } \\
\text { exchange, coded as } 0\end{array}$ \\
\hline Equity $_{\mathrm{j}, \mathrm{t}}$ & $\begin{array}{l}\text { Actual figures of charges or costs on equity accounting divided by the number } \\
\text { of shares outstanding for firm } \mathrm{j} \text {, in year } \mathrm{t} \text {, for those firms that do not exclude } \\
\text { charges or costs on equity accounting, coded as } 0\end{array}$ \\
\hline
\end{tabular}




\begin{tabular}{|c|c|}
\hline Variables (continued) & Descriptions (continued) \\
\hline Other $_{\mathrm{j}, \mathrm{t}}$ & $\begin{array}{l}\text { For compliance firms, Other }{ }_{j, t} \text { includes the costs (e.g., legal costs, Australasia } \\
\text { insurance costs, guarantee and commitment fees, losses of natural disasters, } \\
\text { etc.) that are not classified in any of the specific categories. For non- } \\
\text { compliance firms, Other }{ }_{j, t} \text { is more ambiguous because the firms do not state } \\
\text { what the other expenses are; therefore, we measure Other }{ }_{j, t} \text { for non-compliance } \\
\text { firms as the total income-increasing exclusions minus any of the other seven } \\
\text { individual adjustments divided by the number of shares outstanding for firm } j \text {, } \\
\text { in year } t \text {; for those firms that do not present any adjustments, Other }{ }_{j, t} \text { equals the } \\
\text { total income-increasing adjustments divided by the number of shares } \\
\text { outstanding for firm } j \text {, in year } t \text {. }\end{array}$ \\
\hline MtoB $_{\mathrm{j}, \mathrm{t}}$ & Market-to-book equity ratio for firm $\mathrm{j}$, in year $\mathrm{t}$ \\
\hline $\mathrm{ROE}_{\mathrm{j}, \mathrm{t}}$ & Earnings before tax divided by average equity for firm $\mathrm{j}$, in year $\mathrm{t}$ \\
\hline Size $_{\mathrm{j}, \mathrm{t}}$ & Natural logarithm of firm j's total assets, at beginning of year $t$ \\
\hline Leverage $_{j, t}$ & Short-term and long-term debt divided by total assets for firm $\mathrm{j}$, year $\mathrm{t}$. \\
\hline $\mathrm{SDE}_{\mathrm{j}, \mathrm{t}}$ & $\begin{array}{l}\text { Standard deviation of earnings before tax scaled by beginning total assets of } \\
\text { the firm, computed using a } 5 \text {-year rolling window ending in year } 2014 \text { for firm } \\
j \text {, year } t\end{array}$ \\
\hline $\mathrm{NOA}_{\mathrm{j}, \mathrm{t}}$ & $\begin{array}{l}\text { Shareholders' equity less cash and cash equivalent plus total debt at the } \\
\text { beginning of the year divided by lagged sales }\end{array}$ \\
\hline Sales $G_{\mathrm{j}, \mathrm{t}}$ & $\begin{array}{l}\text { Sales for firm } j \text {, year } t \text { minus the sales for firm } j \text {, year } t-1 \text {, then divided by the } \\
\text { sales for firm } j \text {, year } t \text {. }\end{array}$ \\
\hline Capital $_{\mathrm{j}, \mathrm{t}}$ & $\begin{array}{l}\text { Ratio of net book value of property, plant, and equipment to total assets for } \\
\text { firm j, year } t\end{array}$ \\
\hline BVEPS $_{\mathrm{j}, \mathrm{t}}$ & $\begin{array}{l}\text { Book value of equity divided by the number of outstanding shares for firm } j \text {, } \\
\text { year } t \text {. }\end{array}$ \\
\hline
\end{tabular}

